Article

\title{
Intensification of Mediterranean Goat Production Systems: A Case Study in Northern Morocco
}

\author{
Olivia Florence Godber ${ }^{1, *}$, Boughaleb Farahat Laroussi ${ }^{2}$, Mouad Chentouf ${ }^{2}$ and Richard Wall ${ }^{1}$ \\ 1 Veterinary Parasitology \& Ecology Group, Bristol Life Sciences Building, University of Bristol, \\ Bristol BS8 1TQ, UK; richard.wall@bristol.ac.uk \\ 2 INRA Regional Centre of Tangier, Bd Sidi Mohamed Ben Abdalah 78, Tangier 90010, Morocco; \\ farahatlaroussi@gmail.com (B.F.L.); mouad.chentouf@gmail.com (M.C.) \\ * Correspondence: olivia.godber@bristol.ac.uk; Tel.: +44-117-9289182
}

Academic Editor: Sanzidur Rahman

Received: 27 November 2015; Accepted: 11 April 2016; Published: 14 April 2016

\begin{abstract}
Goats are important contributors to both food and financial security of the resource poor, particularly in marginal environments such as those in the Mediterranean region. To fully understand the feasibility and potential consequences of any intensification or husbandry changes that could contribute to higher outputs, it is important to have a thorough prior understanding of the functional dynamics of these systems. Here the current performance of ten goat holdings in the northern region of Morocco, classified as either commercial milk producers, commercial cheese producers or non-commercial dairy producers, was recorded, based on the Food and Agricultural Organisation and International Centre for Advanced Mediterranean Agronomic Studies (FAO-CIHEAM) technical and economic indicators, to assess whether intensification of dairy production was financially viable. Fecundity and prolificacy rates were comparatively lower than those achieved by many European Mediterranean herds. Both kid and doe mortality were higher on commercial dairy holdings, where dairy sales provided an additional, rather than alternative, source of income to goat sales. Despite this, due to significantly higher expenditure on supplementary feed, gross margin per doe did not differ significantly between holding types. With the exception of indigenous Greek herds, all European Mediterranean herds outperform those of northern Morocco. The study suggests that a low level of supplementary feeding is constraining goat dairy production in northern Morocco, and that the current high cost and limited availability of additional supplementary feed restricts the financial viability of intensification. Alternative feeding strategies within a participatory approach that might ameliorate these problems, and value chain constraints, are discussed.
\end{abstract}

Keywords: goats; bio-economics; marginal environments; Morocco; Mediterranean

\section{Introduction}

Goats are an important source of protein through dairy and meat production, contributing to both the food and financial security of households, particularly the resource poor [1]. Their flexible feeding habits and ability to utilise sparse vegetation are attributes which contribute to the importance of goats in marginal habitats. The type of intensification required for commercial dairy production is questioned in an attempt to meet growing food demand and improve livelihoods [2-5]. To fully understand the feasibility and potential consequences of such intensification, it is important to have a thorough initial understanding of the functional dynamics of the system.

Communities in the Mediterranean region are particularly dependent on goat production [6]. There have been a number of recent government or public authority initiatives in the region to promote an increase in dairy production [7]. However, no studies to the authors' knowledge have examined the financial viability of such initiatives in detail. The aim of the present study, therefore, was to 
examine the financial and production consequences of attempts to achieve intensification through commercialisation of dairy products in goat Mediterranean production systems: specifically did intensification allow producers to achieve higher financial and production outputs?

The analysis focussed on the northern region of Morocco as a case study. Here the goat population is estimated at 788,000 animals ( $43 \%$ of ruminants in the region and $12 \%$ of the national goat population) [8] and goat farming has an important socio-economic role and contributes to local food security [9], particularly through meat production. Ten representative goat holdings were selected. These included commercial milk producers, commercial cheese producers and non-commercial dairy producers. The data collected for these northern Moroccan farms are compared to other extensive and semi-intensive Mediterranean grazing goat systems.

\section{Experimental Section}

Data based on the the Food and Agricultural Organisation and International Centre for Advanced Mediterranean Agronomic Studies (FAO-CIHEAM) technical and economic indicators [10] were collected monthly over a three year period between September 2009 and August 2012. These indicators provide a general system to analyse and compare different sheep and goat production systems, compiled and validated by a group of experts in France, Spain (Andalusia, Basque Country), Northern Portugal and Northern Morocco. Indicators include those concerning the land cover, farm labour force, livestock, structure of the goat herd, technical aspects (reproduction, feeding, milk production, meat production, cheese making) and economics (operational expenses, gross earnings).

\subsection{Data Collection and Questionnaire Design}

Ten small-scale goat holdings representative of the northern Moroccan region of Tanger-Tetouan were selected based on their production objective: three commercial cheese producers, four commercial milk producers and three non-commercial dairy producers. The latter acted as a control group (Table 1). The region has a Mediterranean climate (Köppen classification Csa) and the environment is characterised by both mountains and plains. Goat production is predominantly extensive, relying on grazing of pasture and rangelands throughout the year to provide nutrition. For meat systems, supplementation may be offered, particularly in the period before the Islamic holiday of Eid Al Adha (sacrifice feast). Dairy systems are all semi-extensive but most goats receive routine concentrate supplementation in their diets.

Data were collected by interviewing farmers monthly between September 2009 and August 2012. The questionnaire used to collect the information was based on the FAO-CIHEAM technical and economic indicators, a full description of which can be found in Touissant et al. [10].

Table 1. The location and altitude of the goat holdings used in the study to assess the financial viability of intensification in northern Moroccan goat herds.

\begin{tabular}{cccccc}
\hline Holding ID & $\begin{array}{c}\text { Dairy Production } \\
\text { Objective }\end{array}$ & Location & $\begin{array}{c}\text { Altitude } \\
\text { (m asl) }\end{array}$ & Province/Prefecture & $\begin{array}{c}\text { Rural } \\
\text { Commune }\end{array}$ \\
\hline $\mathrm{A}$ & $\mathrm{CC}$ & $35^{\circ} 33^{\prime} \mathrm{N}, 5^{\circ} 53^{\prime} \mathrm{W}$ & 9 & Tanger-Asilah & Jbel Hbib \\
$\mathrm{B}$ & $\mathrm{CM}$ & $35^{\circ} 33^{\prime} \mathrm{N}, 5^{\circ} 53^{\prime} \mathrm{W}$ & 9 & Tanger-Asilah & Jbel Hbib \\
$\mathrm{C}$ & $\mathrm{CM}$ & $35^{\circ} 17^{\prime} \mathrm{N}, 5^{\circ} 34^{\prime} \mathrm{W}$ & 418 & Larache & Beni Arouss \\
$\mathrm{D}$ & $\mathrm{CM}$ & $35^{\circ} 17^{\prime} \mathrm{N}, 5^{\circ} 36^{\prime} \mathrm{W}$ & 361 & Larache & Beni Arouss \\
$\mathrm{E}$ & $\mathrm{CM}$ & $35^{\circ} 21^{\prime} \mathrm{N}, 5^{\circ} 37^{\prime} \mathrm{W}$ & 289 & Larache & Beni Arouss \\
$\mathrm{F}$ & $\mathrm{CC}$ & $35^{\circ} 01^{\prime} \mathrm{N}, 5^{\circ} 48^{\prime} \mathrm{W}$ & 98 & Larache & Boujediane \\
$\mathrm{G}$ & $\mathrm{CC}$ & $35^{\circ} 41^{\prime} \mathrm{N}, 5^{\circ} 20^{\prime} \mathrm{W}$ & 7 & M'diq-Fnideq & Bouzaghlal \\
$\mathrm{H}$ & $\mathrm{NC}$ & $35^{\circ} 07^{\prime} \mathrm{N}, 5^{\circ} 15^{\prime} \mathrm{W}$ & 585 & Chefchaouen & Bab Taza \\
$\mathrm{I}$ & $\mathrm{NC}$ & $35^{\circ} 09^{\prime} \mathrm{N}, 5^{\circ} 16^{\prime} \mathrm{W}$ & 506 & Chefchaouen & Dardara \\
$\mathrm{J}$ & $\mathrm{NC}$ & $35^{\circ} 07^{\prime} \mathrm{N}, 5^{\circ} 15^{\prime} \mathrm{W}$ & 585 & Chefchaouen & Bab Taza \\
\hline
\end{tabular}

$\mathrm{CC}$, commercial cheese producer, $\mathrm{CM}$, commercial milk producer, $\mathrm{NC}$, non-commercial dairy producer. 


\subsection{Calculation of Reproductive Parameters}

Seven reproductive parameters were calculated, following Pittavino et al. [11] (Table 2), as reproductive performance and a high rate of parturition are key drivers for continued lactation for dairy production and the production of offspring for meat production [12]. These reproductive parameters included herd fertility rate (the proportion of does becoming pregnant within a year), herd prolificacy (the ratio of kids born to the number of females becoming pregnant within a year; a prolificacy greater than one indicates the occurrence of multiple births by does), herd fecundity (the product of fertility and prolificacy, indicating the ratio between the number of kids born and the total number of does in the herd), new birth rate (the proportion of kids born that survive to weaning), herd reproduction rate (the product of new birth rate and fecundity, indicating the ratio of kids surviving to weaning to the total number of does in the herd), herd replacement rate (the rate that kids need to be introduced into the herd to replace all goats removed from the herd due to mortality, slaughter or sale; this is inversely proportional to the total number of kids surviving to weaning per doe lifetime), reproductive life of the doe (the number of years the doe is reproductively active for) and the lifetime productivity of the doe (the total number of surviving kids produced in a doe's lifetime).

Table 2. The equations for calculating the reproductive parameters, adapted from Pittavino et al. (2014) [11].

\begin{tabular}{ccc}
\hline Reproductive Parameter & Symbol & Equation \\
\hline Fertility & $f$ & $=\frac{\text { Total does kidding }+ \text { number of abortions }}{\text { Number of does in herd }}$ \\
Prolificacy & $p$ & $=\frac{\text { Total kids born }}{\text { Total does kidding }+ \text { number of abortions }}$ \\
Fecundity & $\varphi$ & $=\mathrm{f} \cdot \mathrm{p}$ \\
New birth rate & $l$ & $=1-$ Kid mortality \\
Reproduction rate & $r$ & $=\varphi \cdot l=f \cdot p \cdot l$ \\
Goat losses & $\mu$ & $=\Sigma[$ goat mortality, goat culls, goats sold $]$ \\
Replacement rate of the herd & $\alpha_{\text {herd }}$ & $=\frac{\mu_{\text {herd }}}{\mu_{\text {doe }}}$ \\
Replacement rate of the doe & $\alpha_{\text {doe }}$ & $=\frac{1}{\mu_{\text {doe }}}$ \\
Reproductive life of the doe & $l_{r}$ & $=l_{r} \cdot r$ \\
Lifetime productivity & &
\end{tabular}

\subsection{Statistical Analyses}

All statistical analyses were carried out in R [13]. Holdings were categorised according to their dairy production status: commercial milk production (CM), commercial cheese production (CC) or non-commercial dairy (NC). As the majority of indicators were not normally distributed, descriptive statistics were calculated through non-parametric methods, including the quartile coefficient of dispersion (also known as the coefficient of quartile variation; QCV [14]), a non-parametric alternative to the coefficient of variation calculated from the interquartile range $\left(\mathrm{Q}_{3}-\mathrm{Q}_{1}\right)$ divided by the median $\left(\mathrm{Q}_{1}\right)$. Where differences between the production objective of holdings (CM, CC or NC) or seasonality are reported, linear (for continuous responses) and generalised linear (for count responses) mixed effects models were fitted by restricted maximum likelihood (REML) and maximum likelihood (ML) with Laplace approximation respectively using the $\mathrm{R}$ lme4 package [15]. Predictor variables were specified as fixed effects and holding identity as a random effect to account for repeated measures throughout the study period. The equation structure was as follows:

$$
\mathrm{Y}_{i}=\mathrm{X}_{\mathrm{i}} \beta_{i}+\mathrm{Z}_{i, j} \mathrm{~b}_{i}+\varepsilon_{i}
$$

where $i$ is a vector of observations, $j$ is a vector of holdings, $Y_{i}$ is the response for observation $i, X_{i}$ is the production objective (when comparing holding type) or month (for seasonal variation) of observation $i, \beta_{i}$ is the regression coefficient for observation $i, Z_{i, j}$ is the random effect of holding $j$ for observation $i, b$ is the random intercept for observation $i$ and $\varepsilon$ is the random error term for observation $i$. 
Inference was based on analysis of variance with F-tests and analysis of deviance with Wald chi-squared tests reported for linear and generalised linear models respectively, both based on Satterthwaite's approximation to degrees of freedom as recommended by Bolker et al. [16]; the $\mathrm{R}$ package lmerTest was used [17]. If significant for categorical predictors, simultaneous tests for general linear hypotheses were run using Tukey's honest significant difference with $p$-values adjusted using the single-step method to account for multiple comparisons and decrease the chance of type I error. Level of significance was set at $p<0.05$ for all tests.

All economic data were recorded in Moroccan Dirhams (MAD) and have been presented in Euros at an exchange rate of $10 \mathrm{MAD}=1 €$.

\section{Results and Discussion}

The average age of holding owners in this study (56 years QCV $=0.18$; Table 3 ) is higher than previously reported in other European Mediterranean studies [18-20]. CC and CM holdings had been running for an average of $13(\mathrm{QCV}=0.37)$ and $11(\mathrm{QCV}=1.18)$ years respectively (Table 3$)$; this corresponds with public authority initiatives for diversification to dairy production in goat herds in Morocco [7]. NC holdings had been established, on average, substantially longer (53 years QCV $=0.32$; Table 3).

\subsection{Land Ownership and Labour}

The average area of land available for each flock was 4 ha $(\mathrm{QCV}=1.38$; combining rented and owned land). This is similar to previous reports for northern Morocco meat and mixed meat/dairy holdings [21] and did not differ significantly between CC, CM or NC holdings (Table 3). In contrast to previous reports stating that NC holdings reserve all arable land for human food crops [22], the present study shows that NC holdings use more arable area for goat feed production (cereals and legumes) than CM or CC holdings (Table 3). Here family members were used for almost all labour, as reported in most other northern Moroccan and European Mediterranean regions [19,20,22-26], with exception of Greece where considerable use of employed labour is reported [27]. Consequently, there are negligible labour costs in the current study. The number of hours worked on the farm did not fluctuate with seasonality of lactation, indicating that there was no increase in labour during kidding periods or peak lactation. Time worked did, however, increase significantly with herd size, as also reported in Portugal and northern Morocco [22,28]. Availability of labour has been reported previously as the main factor limiting herd size on meat farms in northern Morocco [22], indicating that increasing production through herd expansion would be difficult.

\subsection{Herd Dynamics}

The average herd size, of 49 does $(\mathrm{QCV}=1.04$; Table 4$)$, was considerably higher than reported in some other northern Moroccan studies [10,21]. Substantially larger herd sizes are frequently reported in other European Mediterranean regions [18-20,23,25,26,29-36]. The male to female ratio of adults was significantly higher on CC holdings (median $=11.5 \mathrm{QCV}=0.96$ does per buck; Table 4 ) than $\mathrm{CM}$ or NC holdings (Table 4), yet was much lower than the maximum of 25 does per buck recommended in some studies [19] and reported in European Mediterranean herds [18-20,26,27,33,36]. Overall herd size showed significant seasonal variation (Figure 1) with a large decrease in October. This was caused by the sale of juvenile males, at an average of 10 months of age, which removed them from the herd before sexual maturity was reached and limited inbreeding. Adult females, no longer needed for breeding, were also removed at the end of lactation and before recommencement of sexual activity [9]. However, the drop in numbers also coincided with the feast of Eid Al Adha. Consequently, there are both biological and cultural factors driving the seasonality of income from goat sales in northern Morocco. 
Table 3. Descriptive statistics for parameters relating to the holding owner, land and labour utilisation and the presence of other livestock on ten goat holdings in the northern region of Morocco based on monthly data collections between September 2009 and August 2012. Holdings are classified by their dairy production status: commercial cheese (CC, $n=3)$, commercial milk (CM, $n=4)$ and non-commercial dairy (NC, $n=3)$.

\begin{tabular}{|c|c|c|c|c|c|c|c|c|c|c|c|c|}
\hline \multirow{2}{*}{ Parameter } & \multirow{2}{*}{ Units } & \multicolumn{4}{|c|}{ All Holdings } & \multicolumn{2}{|c|}{ CC Holdings } & \multicolumn{2}{|c|}{ CM Holdings } & \multicolumn{2}{|c|}{ NC Holdings } & \multirow{2}{*}{ Significance } \\
\hline & & Min. & Median & Max. & CQV & Median & $\mathrm{CQV}$ & Median & $\mathrm{CQV}$ & Median & CQV & \\
\hline \multicolumn{13}{|l|}{ Holding owner } \\
\hline family size & heads & 1 & 7 & 15 & 0.71 & 8 & 0.63 & 6.5 & 1.12 & 5 & 1.00 & ns \\
\hline age & years & 26 & 56 & 78 & 0.18 & 58.5 & 0.10 & 53 & 0.37 & 55 & 0.11 & ns \\
\hline experience & years & 2 & 38 & 52 & 0.60 & 22 & 0.82 & 29 & 1.07 & 43 & 0.16 & ns \\
\hline $\begin{array}{l}\text { farm established } \\
\text { Land }\end{array}$ & years & 1 & 15 & 55 & 1.63 & $11^{\mathrm{a}}$ & 1.18 & $13^{\mathrm{a}}$ & 0.37 & $53^{b}$ & 0.32 & $*$ \\
\hline $\begin{array}{l}\text { Land } \\
\text { owned }\end{array}$ & hectares & 0 & 2 & 70 & 3.13 & $2^{a b}$ & 5,50 & $0.25^{\mathrm{a}}$ & 550 & $7^{\mathrm{b}}$ & 914 & * \\
\hline rented & hectares & 0 & 0 & 8 & - & 1 & & 1.50 & 2.17 & 0 & - & ns \\
\hline total & hectares & 0 & 4 & 78 & 1.38 & 3 & 3.50 & 2.25 & 2.61 & 7 & 9.14 & ns \\
\hline cereal feed production & hectares & 0 & 0 & 20 & - & $0^{\mathrm{ab}}$ & - & $0.00^{\mathrm{a}}$ & - & $2^{b}$ & 3.50 & $*$ \\
\hline legume feed production & hectares & 0 & 0 & 7 & - & $0^{\mathrm{a}}$ & - & $0.00^{\mathrm{a}}$ & - & $1^{b}$ & 3.75 & * \\
\hline grazing & hectares & 0 & 0 & 20 & - & 1 & 1.00 & 0.00 & - & 0 & - & ns \\
\hline \multicolumn{12}{|l|}{ Labour } & ns \\
\hline \multirow[t]{2}{*}{ family } & hours· year ${ }^{-1}$ & 1800 & 3280 & 9940 & 0.63 & 4630 & 0.00 & 2700 & 0.21 & 3700 & 0.99 & ns \\
\hline & hours. week $^{-1}$ & 30 & 64 & 218 & 0.64 & 90 & 0.00 & 52 & 0.29 & 120 & 0.75 & ns \\
\hline \multirow[t]{2}{*}{ paid } & hours. year $^{-1}$ & 0 & 0 & 3090 & - & 0 & - & 0 & - & 0 & - & ns \\
\hline & hours. week $^{-1}$ & 0 & 0 & 60 & - & 0 & - & 0 & - & 0 & - & ns \\
\hline \multirow[t]{2}{*}{ total } & hours year $^{-1}$ & 1800 & 3470 & 10900 & 0.60 & 4630 & 00.0 & 2700 & 0.18 & 4110 & 0.92 & ns \\
\hline & hours. week $^{-1}$ & 30 & 64 & 278 & 0.64 & 90 & 0.01 & 52 & 0.29 & 120 & 1.06 & ns \\
\hline \multicolumn{13}{|l|}{ Other livestock present } \\
\hline cattle & heads & 0 & 0 & 14 & - & $10^{\mathrm{a}}$ & 1.00 & $0^{b}$ & - & $0^{\mathrm{ab}}$ & - & * \\
\hline sheep & heads & 0 & 0 & 42 & - & 14 & 1.79 & 0 & - & 0 & - & ns \\
\hline
\end{tabular}

$C Q V=$ coefficient of quartile variation calculated from the interquartile range $\left(Q_{3}-Q_{1}\right)$ divided by the median $\left(Q_{1}\right)$; significant difference between production objectives after accounting

for repeated measured is indicated by different subscripts; level of significance is indicated by asterisks: ${ }^{*} p<0.05,{ }^{* *} p<0.01,{ }^{* * *} p<0.001$; ns, not significant. 
Table 4. Descriptive statistics for parameters relating to the herd structure and bio-economics of ten goat holdings in the northern region of Morocco based on monthly data collections between September 2009 and August 2012. Holdings are classified by their dairy production status: commercial cheese (CC, $n=3)$, commercial milk $(\mathrm{CM}, n=4)$ and non-commercial dairy $(\mathrm{NC}, n=3)$.

\begin{tabular}{|c|c|c|c|c|c|c|c|c|c|c|c|c|}
\hline \multirow{2}{*}{ Parameter } & \multirow{2}{*}{ Units } & \multicolumn{4}{|c|}{ All Holdings } & \multicolumn{2}{|c|}{ CC Holdings } & \multicolumn{2}{|c|}{ CM Holdings } & \multicolumn{2}{|c|}{ NC Holdings } & \multirow{2}{*}{ Significance } \\
\hline & & Min. & Median & Max. & CQV & Median & $\mathrm{CQV}$ & Median & CQV & Median & CQV & \\
\hline \multicolumn{13}{|l|}{ Herd structure } \\
\hline total herd size & heads & 45 & 94 & 484 & 0.92 & 94 & 0.61 & 76 & 0.59 & 149 & 1.11 & ns \\
\hline \multirow{2}{*}{ does } & heads & 20 & 49 & 186 & 1.04 & 45 & 1.02 & 42 & 0.53 & 69 & 1.51 & ns \\
\hline & proportion & 0.36 & 0.53 & 0.70 & 0.23 & $0.50^{\mathrm{a}}$ & 0.28 & $0.55^{\mathrm{a}}$ & 0.11 & $0.46^{\mathrm{b}}$ & 0.26 & $* * *$ \\
\hline \multirow[t]{2}{*}{ bucks } & heads & 0 & 7 & 77 & 1.17 & 3 & 1.67 & 6 & 0.88 & 22 & 1.36 & ns \\
\hline & proportion & 0.00 & 0.08 & 0.32 & 1.12 & $0.04^{\mathrm{a}}$ & 0.87 & $0.09 \mathrm{ab}$ & 0.85 & $0.11^{\mathrm{b}}$ & 0.58 & $* *$ \\
\hline buck to doe ratio & ratio & $1: 2$ & $1: 6$ & $1: 130$ & 1.50 & 11.5 & $0.96^{\mathrm{a}}$ & $1: 6$ & $1.25^{\mathrm{b}}$ & $1: 4$ & $0.28^{c}$ & $* * *$ \\
\hline \multirow[t]{2}{*}{ kids and juveniles } & heads & 15 & 36 & 246 & 1.07 & 40 & 1.05 & 31.5 & 0.89 & 70 & 0.94 & ns \\
\hline & proportion & 0.15 & 0.42 & 1.00 & 0.28 & 0.42 & 0.20 & 0.38 & 0.31 & 0.47 & 0.12 & ns \\
\hline \multicolumn{13}{|l|}{ Kidding } \\
\hline twins & proportion & 0.00 & 0.21 & 0.75 & 0.88 & 0.11 & 2.49 & 0.27 & 1.23 & 0.17 & 0.39 & ns \\
\hline singles & proportion & 0.23 & 0.79 & 1.00 & 0.24 & 0.89 & 0.31 & 0.71 & 0.48 & 0.83 & 0.10 & ns \\
\hline male to female ratio & proportion & 0.20 & 0.50 & 0.65 & 0.13 & 0.49 & 0.16 & 0.48 & 0.17 & 0.51 & 0.04 & ns \\
\hline \multicolumn{13}{|l|}{ Reproductive success } \\
\hline stillbirths & rate & 0.00 & 0.00 & 0.27 & - & 0.00 & - & 0.00 & - & 0.00 & - & ns \\
\hline abortions & rate & 0.00 & 0.01 & 0.63 & 16.3 & $0.01^{\mathrm{a}}$ & 6.24 & $0.06^{\mathrm{b}}$ & 2.07 & $0.00^{\mathrm{c}}$ & - & $* * *$ \\
\hline fertility & rate & 0.30 & 0.85 & 1.00 & 0.39 & 0.94 & 0.17 & 0.71 & 0.43 & 0.78 & 0.54 & ns \\
\hline prolificacy & rate & 0.75 & 1.19 & 1.81 & 0.18 & 1.09 & 0.16 & 1.15 & 0.37 & 1.23 & 0.86 & ns \\
\hline fecundity & rate & 0.35 & 0.98 & 1.57 & 0.45 & 1.05 & 0.10 & 0.84 & 0.55 & 0.96 & 0.57 & ns \\
\hline new birth rate & rate & 0.36 & 0.88 & 1.00 & 0.32 & $0.82^{a}$ & 0.25 & $0.80^{\mathrm{a}}$ & 0.34 & $0.96^{\mathrm{b}}$ & 0.10 & $* *$ \\
\hline reproduction rate & rate & 0.19 & 0.76 & 1.24 & 0.47 & 0.76 & 0.25 & 0.70 & 0.47 & 0.88 & 0.92 & ns \\
\hline
\end{tabular}


Table 4. Cont.

\begin{tabular}{|c|c|c|c|c|c|c|c|c|c|c|c|c|}
\hline \multirow{2}{*}{ Parameter } & \multirow{2}{*}{ Units } & \multicolumn{4}{|c|}{ All Holdings } & \multicolumn{2}{|c|}{ CC Holdings } & \multicolumn{2}{|c|}{ CM Holdings } & \multicolumn{2}{|c|}{ NC Holdings } & \multirow{2}{*}{ Significance } \\
\hline & & Min. & Median & Max. & $\mathrm{CQV}$ & Median & $\mathrm{CQV}$ & Median & $\mathrm{CQV}$ & Median & $\mathrm{CQV}$ & \\
\hline \multicolumn{13}{|l|}{ Herd turnover } \\
\hline herd replacement rate & rate & 0.11 & 0.45 & 1.29 & 0.86 & 0.46 & 0.23 & 0.55 & 0.76 & 0.29 & 1.41 & ns \\
\hline doe replacement rate & rate & 0.00 & 0.21 & 1.78 & 1.80 & $0.16^{\mathrm{a}}$ & 0.60 & $0.41^{\mathrm{b}}$ & 1.08 & $0.17^{a b}$ & 1.51 & $*$ \\
\hline reproductive life of the doe & years & 1 & 6 & 23 & 1.00 & 6.82 & 0.54 & 4.38 & 0.88 & 6.25 & 1.17 & ns \\
\hline doe cull rate & rate & 0.00 & 0.17 & 0.89 & 1.21 & $0.13^{\mathrm{ab}}$ & 0.44 & $0.23^{a}$ & 1.25 & $0.16^{b}$ & 0.52 & * \\
\hline productivity & heads & 1 & 5 & 20 & 1.00 & 5.50 & 0.68 & 2.50 & 1.00 & 6 & 0.83 & ns \\
\hline Mortality & & & & & & & & & & & & \\
\hline perinatal (within 7 days of birth) & rate & 0.00 & 0.02 & 0.60 & 4.97 & 0.03 & 3.36 & 0.03 & 1.50 & 0.00 & - & ns \\
\hline $\begin{array}{l}\text { pre-weaning (between } 7 \text { and } \\
90 \text { days of birth) }\end{array}$ & rate & 0.00 & 0.07 & 0.48 & 2.27 & 0.11 & 1.39 & 0.10 & 1.54 & 0.02 & 4.97 & ns \\
\hline overall kid & rate & 0.00 & 0.12 & 0.64 & 2.43 & $0.18^{a}$ & 1.12 & $0.20^{\mathrm{a}}$ & 1.39 & $0.04^{\mathrm{b}}$ & 2.05 & $* *$ \\
\hline doe & rate & 0.00 & 0.02 & 0.44 & 5.97 & $0.02^{\mathrm{a}}$ & 2.02 & $0.07^{\mathrm{b}}$ & 2.64 & $0.00^{c}$ & - & $* * *$ \\
\hline buck & rate & 0.00 & 0.00 & 0.50 & - & 0.00 & - & 0.00 & - & 0.00 & - & ns \\
\hline juvenile female & rate & 0.00 & 0.00 & 0.57 & - & 0.00 & - & 0.00 & - & 0.00 & - & ns \\
\hline juvenile male & rate & 0.00 & 0.00 & 1.00 & - & 0.00 & - & 0.00 & - & 0.00 & - & ns \\
\hline
\end{tabular}

$\mathrm{CQV}=$ coefficient of quartile variation calculated from the interquartile range $\left(\mathrm{Q}_{3}-\mathrm{Q}_{1}\right)$ divided by the median $\left(\mathrm{Q}_{1}\right)$; significant difference between production objectives after accounting

$\mathrm{CQV}=$ coefficient of quartile variation calculated from the interquartile range $\left(\mathrm{Q}_{3}-\mathrm{Q}_{1}\right)$ divided by the median $\left(\mathrm{Q}_{1}\right)$; significant difference between production obje
for repeated measured is indicated by different subscripts; level of significance is indicated by asterisks: ${ }^{*} p<0.05, * * 0<0.01$, $* * * *<0.001$; ns, not significant. 


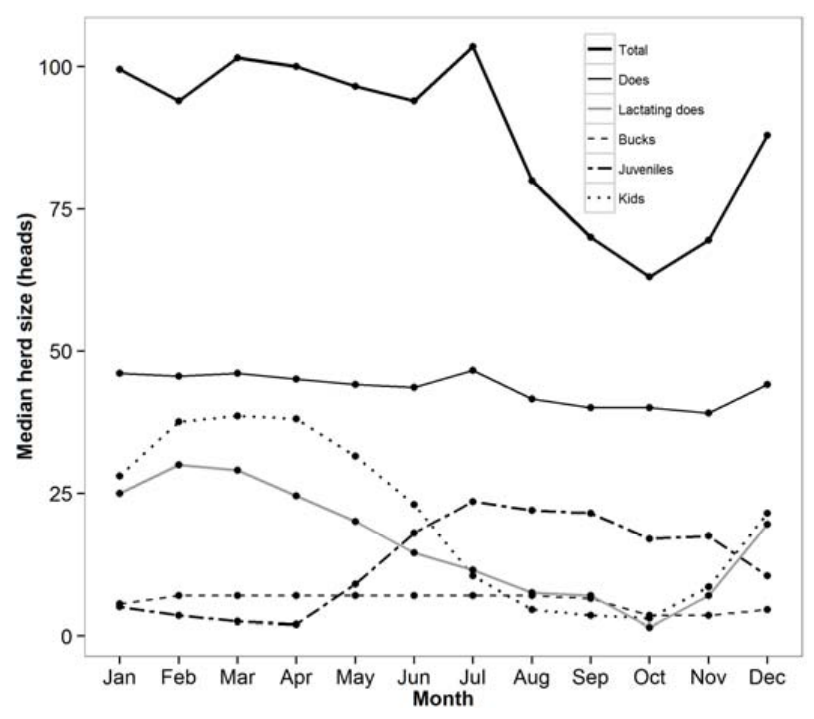

Figure 1. Median herd size of goat holdings in northern Morocco based on monthly data collections between September 2009 and August 2012.

\subsection{Reproduction}

Seven reproductive parameters were calculated, following Pittavino et al. [11] (Tables 2 and 4). Seasonality of reproduction has been reported previously in northern Morocco $[9,22]$ and in the current study kidding was concentrated between November and February ( $66 \%$ of kidding occurred during this period). This seasonal parturition limits potential milk yield and meat income. Approximately $25 \%$ of kiddings produced twins. Although twin births are preferable for meat production, as more animals are available for sale, single births may benefit producers in this region by allowing nutritional requirements to be met more feasibly, particularly as supplementary feed is not readily available or affordable; mortality of twin-born kids increases when forage supply falls [37].

Abortions were recorded on nine of the ten holdings, with a significantly higher rate of abortion on CM holdings than CC or NC holdings (Table 4). However, overall abortive rate was less than $0.5 \%$, as previously reported for extensive goat herds in Tuscany [38] and substantially lower than the value of $2.97 \%$ reported in Spain [19]. Still births were reported rarely.

There were no significant differences in the fertility, prolificacy or fecundity rates between holding types (Table 4). Similar fertility rates to the current study $(85 \% \mathrm{QCV}=0.39$; Table 4$)$ were observed previously in northern Morocco [21] and Sardinia [29], although both higher (92\%-93\%) and lower $(79 \%-80 \%)$ rates have been observed in Morocco [21,22,24] and Andalusia [25,33], suggesting that fertility rate is highly variable. Prolificacy rates above 1.35 have been reported in northern Moroccan [24] and European Mediterranean herds [20,26,29,33] which are considerably higher than the current study $(1.19 \mathrm{QCV}=0.18$; Table 4$)$. Average fecundity in this study, of $0.98(\mathrm{QCV}=0.45$; Table 4), which takes into account both fertility and prolificacy, shows that almost one kid was produced per doe per year, as reported for meat herds in northern Morocco receiving no supplementation [22]. As does tended to be supplemented in the current study, albeit minimally, higher fecundity rates might have been expected; higher levels of supplementation may be required if fecundity of dairy goats is to be improved in northern Morocco. A higher fecundity of 1.19 was reported in Sardinia [29], despite similar fertility rates; these herds had longer grazing periods compared to herds in the current study ( $14 \mathrm{~h}$ vs. $8 \mathrm{~h}$, respectively) suggesting again that nutrition is having an effect; there is no information, however, on level of supplementary feeding in the Sardinian study. When compared to the fecundity rate of 0.98 , the new birth rate of $0.88(\mathrm{QCV}=0.32$; Table 4$)$ observed here indicates problems associated with kid survival to weaning. New birth rates, ranging between 1.14 and 1.72, were observed in grazing goats in Palmera [20] and Greece [27], substantially higher than reported 
here. New birth rate was, however, significantly higher (more kids survived to weaning per doe in the herd) on NC holdings than CM and CC holdings (Table 4), suggesting that kid mortality increased with intensity of production in the study region: significantly lower kid mortality rates were found on NC than CC and CM holdings (Figure 2). Previous Moroccan studies also show lower mortality rates on NC than CC or CM holdings [22,24,39] and in southern Spain lower kid mortality rates were reported for intensive, semi-intensive and semi-extensive herds respectively [23]; high kid mortality in Morocco has previously been attributed to inadequate feeding due to poor pasture productivity, inefficient use of crop residues and a lack of information on feed concentrate feed quality [40]. Inadequate artificial rearing practices on more intensive holdings may also contribute to higher kid mortality rates [41].

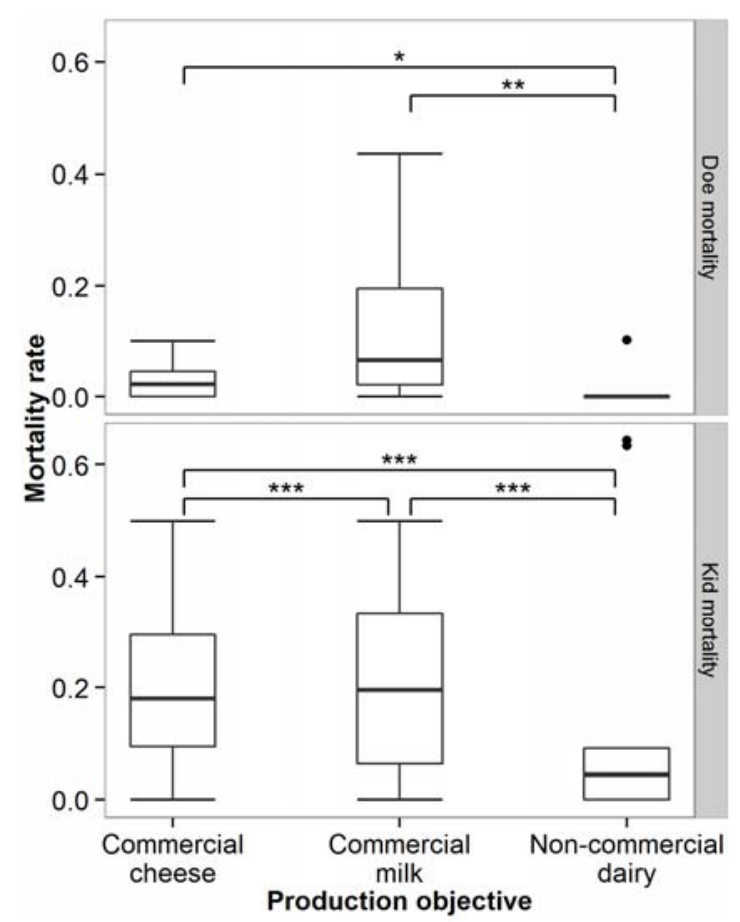

Figure 2. Overall reported doe and kid mortality on goat holdings in northern Morocco based on monthly data collections between September 2009 and August 2012. Holdings were classified by dairy production status: commercial milk, commercial cheese and non-commerical dairy. Asterisks indicate signficant differences after controlling for repeated measures: ${ }^{*} p<0.05,{ }^{* *} p<0.01,{ }^{* * *} p<0.001$.

Doe mortality rates differed significantly between holding types (Figure 2). These rates were higher than reported previously in northern Morocco [24] but lower than in semi-intensive and semi-extensive holdings in southern Spain [23]. Cull rates were also higher for CM than CC and NC holdings (Table 4), due to the practice of more selective culling which contributed to the higher doe replacement rate of $\mathrm{CM}$ holdings $(0.41 \mathrm{QCV}=1.08$; Table 4$)$. Health problems associated with dairy production were not considered in this study, but may have contributed to higher kid mortality, doe mortality and doe culls. These may have been due to nutritional insults. Average reproductive life, equivalent to number of lactations achieved in a lifetime, was six years ( $Q C V=1.00$, Table 4$)$, similar to that found in Greek herds [27]. Enhancing reproductive life of the doe can increase profits through increased sales (as fewer offspring are required as replacements), more selective culling (to increase health and productivity) [42] and herd expansion. Reproductive performance and a high rate of parturition are vital for continued lactation for dairy production, and to produce offspring for meat production [12]. Therefore optimising reproductive performance is essential for both diversification and intensification. 


\subsection{Dairy Production}

Dairy income was highly seasonal, due to the seasonality of reproduction and lactation, but the price received per litre of milk (Table 5) did not differ across the year. The milk available per doe for sale was higher on CM than CC holdings (Figure 3). This was similar to that found in France [30] but with a smaller difference between holding types. Milk yield per doe on CC holdings was substantially lower than previous reports for northern Morocco (24.4 vs. $119 \mathrm{~L} \cdot$ doe $^{-1}$ respectively; Table 5) [24], which were considered low in comparison to European Mediterranean herds [26,30]. Milk yield per doe on CM holdings was similar to previous reports for intensive CM holdings in northern Morocco [7] and indigenous Greek herds [27] but was still substantially lower than other European Mediterranean herds $[20,25-27,30,32-34,43]$, where average annual yields as high as $730 \mathrm{~L} \cdot \mathrm{doe}^{-1}$ were reported in French grazing herds receiving supplementation [31], highlighting the necessity of supplementation for dairy production. Dairy income made a greater contribution to total income on $\mathrm{CM}$ than $\mathrm{CC}$ holdings ( $54.6 \% \mathrm{QCV}=0.35$ and $38.8 \% \mathrm{QCV}=1.46$ for $\mathrm{CM}$ and CC, respectively; Table 5) as reported in other studies for both CC [26] and CM holdings [26,27,29]. In contrast, non-indigenous Greek herds reported a higher dairy contribution to total income ( $>70 \%$ [27]). Dairy income per doe was substantially lower in the current study than seen in other European Mediterranean herds [23,25-27,31,33,34,43], with the exception of indigenous Greek herds, which were similar to those reported here [27].

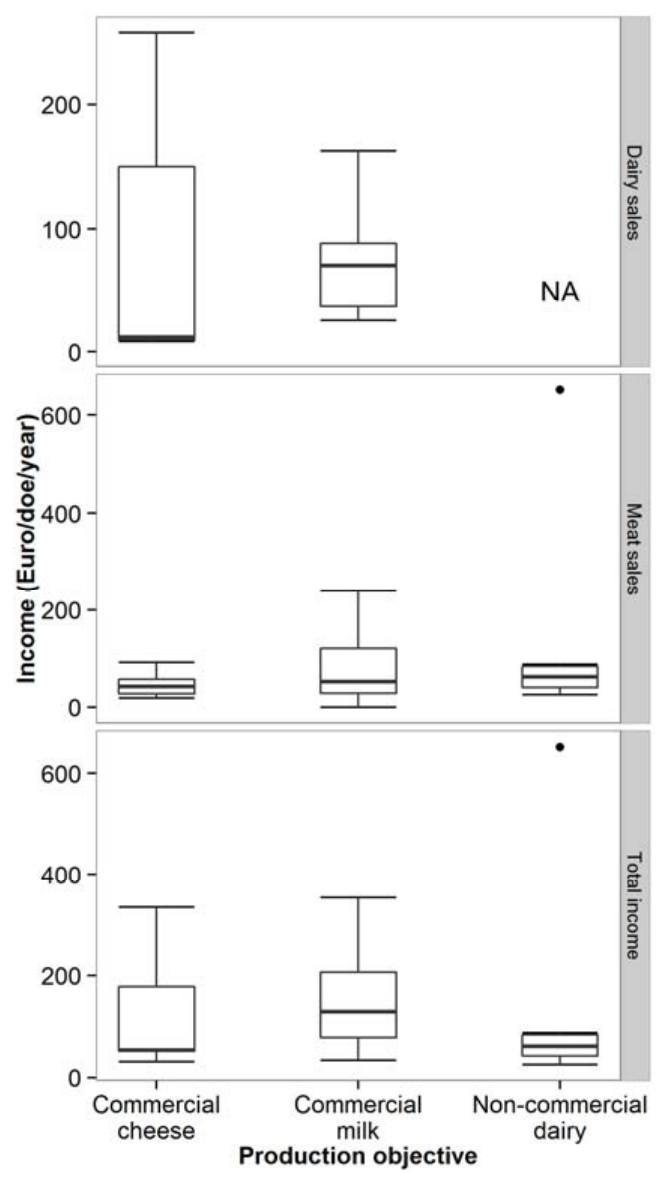

Figure 3. The annual income from dairy sales, goat sales and total annual income; on goat holdings in northern Morocco based on monthly data collections between September 2009 and August 2012. Holdings were classified by dairy production status: commercial milk, commercial cheese and non-commercial dairy. 
Table 5. Descriptive statistics for parameters relating to the dairy production on ten goat holdings in the northern region of Morocco based on monthly data collections between September 2009 and August 2012. Holdings are classified by their dairy production status: commercial cheese (CC, $n=3)$, commercial milk (CM, $n=4)$ and non-commercial dairy $(\mathrm{NC}, n=3)$.

\begin{tabular}{|c|c|c|c|c|c|c|c|c|c|c|c|c|}
\hline \multirow{2}{*}{ Parameter } & \multirow{2}{*}{ Units } & \multicolumn{4}{|c|}{ All Holdings } & \multicolumn{2}{|c|}{ CC Holdings } & \multicolumn{2}{|c|}{ CM Holdings } & \multicolumn{2}{|c|}{ NC Holdings } & \multirow{2}{*}{ Significance } \\
\hline & & Min. & Median & Max. & CQV & Median & CQV & Median & CQV & Median & CQV & \\
\hline \multirow{2}{*}{ Total milk production } & litres & 451 & 3570 & 19600 & 1.14 & 1980 & 1.64 & 5990 & 0.66 & 1770 & 1.62 & ns \\
\hline & litres $\cdot$ doe $^{-1} \cdot$ year $^{-1}$ & 5.59 & 63.9 & 408 & 1.80 & 24.4 & 4.77 & 134 & 0.73 & 25.7 & 0.30 & ns \\
\hline \multirow{4}{*}{$\begin{array}{l}\text { Home-consumption } \\
\text { milk }\end{array}$} & & & & & & & & & & & & \\
\hline & litres & 120 & 360 & 3480 & 1.31 & $174^{\mathrm{a}}$ & 0.92 & $360^{a}$ & 0.38 & $1620^{\mathrm{b}}$ & 1.56 & ** \\
\hline & litres doe $^{-1} \cdot$ year $^{-1}$ & 1.64 & 10.4 & 79.6 & 1.09 & $4.14^{\mathrm{a}}$ & 1.05 & $11.1^{\mathrm{ab}}$ & 0.59 & $23.5^{\mathrm{b}}$ & 0.35 & * \\
\hline & litres. person ${ }^{-1}$ & $\begin{array}{l}1.07 \\
13.6\end{array}$ & 65.6 & 660 & 2.37 & $23.3^{\mathrm{a}}$ & 0.74 & $100^{a b}$ & 1.53 & $162^{b}$ & 1.98 & $* * *$ \\
\hline \multirow[t]{3}{*}{ cheese } & litres & 0 & 151 & 1380 & 1.76 & $252^{a}$ & 0.52 & $0^{\mathrm{b}}$ & - & $208^{a}$ & 1.45 & $* *$ \\
\hline & litres $\cdot$ doe $^{-1} \cdot$ year $^{-1}$ & 0 & 1.96 & 53.1 & 2.11 & $4.92^{\mathrm{a}}$ & 0.74 & $0^{\mathrm{b}}$ & - & $3.44^{\mathrm{a}}$ & 0.71 & ** \\
\hline & litres. person ${ }^{-1}$ & 0 & 19.9 & 276 & 2.08 & $34.8^{\mathrm{a}}$ & 0.47 & $0^{\mathrm{b}}$ & - & $30^{\mathrm{a}}$ & 2.51 & * \\
\hline \multirow[t]{2}{*}{ total dairy } & litres & 160 & 495 & 3760 & 1.04 & $486^{\mathrm{a}}$ & 0.54 & $360^{\mathrm{a}}$ & 0.38 & $1770^{\mathrm{b}}$ & 1.62 & * \\
\hline & litres. person ${ }^{-1}$ & 23.8 & 96 & 752 & 1.72 & 57.3 & 0.42 & 100 & 1.81 & 208 & 2.72 & ns \\
\hline \multirow[t]{4}{*}{ Dairy sales } & litres $\cdot$ doe $^{-1} \cdot$ year $^{-1}$ & 16.2 & 111 & 408 & 1.14 & 12 & 9.48 & 128 & 0.98 & - & - & ns \\
\hline & Euro litre $^{-1}$ & - & - & - & - & 1.30 & 0.42 & 0.6 & 0.33 & - & - & - \\
\hline & Euro. year ${ }^{-1}$ & 330 & 2650 & 7800 & 1.56 & 1040 & 4.46 & 2970 & 0.91 & - & - & ns \\
\hline & Euro $\cdot$ doe $^{-1}$ & 6.94 & 46 & 258 & 1.70 & 11.9 & 11.8 & 70.6 & 0.73 & - & - & ns \\
\hline Proportion to total income & proportion & 0.09 & 0.44 & 0.99 & 0.78 & 0.39 & 1.46 & 0.55 & 0.35 & - & - & ns \\
\hline
\end{tabular}

$\mathrm{CQV}=$ coefficient of quartile variation calculated from the interquartile range $\left(\mathrm{Q}_{3}-\mathrm{Q}_{1}\right)$ divided by the median $\left(\mathrm{Q}_{1}\right)$; significant difference between production objectives after accounting for repeated measured is indicated by different subscripts; level of significance is indicated by asterisks: ${ }^{*} p<0.05,{ }^{* *} p<0.01,{ }^{* * *} p<0.001$; ns, not significant. 


\subsection{Goat Sales}

The data do not allow the purpose of the sale of goats to be distinguished (i.e., for slaughter, fattening or reproduction purposes). There was no significant difference in overall number of males and females sold, though there was a tendency to sell males as juveniles $(<12$ months of age; Table 6$)$ and females as adults ( $>12$ months of age; Table 6). The majority of juvenile females were retained by herds, most likely as replacement stock for culled does. This may also be due to animals being sold by weight, resulting in faster growing females being sold and those growing more slowly retained as replacements; this can increase their age at first kidding due to later sexual maturity, with negative effects on economic returns [44]. Kid sales were rare (Table 6), in contrast with previous reports for CC herds in northern Morocco and dairy herds in Andalusia and Greece [24,27,33]. However, more kids were sold on CM than CC or NC holdings (Table 6), potentially to optimise income. The removal of kids allows a greater yield of milk to be sold and their sale is likely to be considered more favourable than hand rearing with milk replacer, both economically and in terms of labour requirements.

The annual income from goat sales per doe did not differ significantly between holding types, averaging $46.9 € \cdot \mathrm{doe}^{-1}(\mathrm{QCV}=0.95$; Table 6), highlighting its importance to all producers (Figure 3). This was equivalent to that reported previously for CC holdings in northern Morocco [39] and exceeded values reported for Portuguese [35] and Andalusian [33] dairy holdings. However, both meat and mixed meat/milk holdings in northern Morocco [39] and Spanish dairy holdings [43] have reported higher values. The contribution of sales to income averaged 100\% (QCV $=0.00), 61.2 \%(\mathrm{QCV}=0.88)$ and $42.8 \%(\mathrm{QCV}=0.51)$ on NC, CC and CM holdings respectively (Table 6), showing dairy production provided an additional rather than alternative income for CC and $\mathrm{CM}$ holdings and contributes to both increased food and financial income. This is logical as sales are predominantly of males and cull does; neither are required for the production of milk (on commercial dairy holdings) or new animals for sale (on non-commercial dairy holdings).

\subsection{Feeding Practices}

Supplementary feeding was practiced across nine of the ten holdings, in contrast with previous reports of meat farms in northern Morocco with no concentrate feeding [21,22]. Significantly more concentrates were fed per doe on CM than CC or NC holdings (Figure 4), indicating that milk production relies on supplementary feeding. Forage supplementation was rarely reported in the current study or previous northern Moroccan studies [24], possibly due to the high price of forage in this region [42] which contrasts with reports from European Mediterranean studies [20,23,25,27,32-34,36]. Supplementation with concentrates has been previously reported for commercial dairy holdings in northern Morocco $[7,24]$ and is common practice on European Mediterranean holdings [20,23,25,27,29,31,34,36], but at much higher levels than in the current study, which showed a significant positive relationship between the level of concentrate feeding and milk yield per doe. This positive relationship is also reported for French dairy herds achieving very high milk yields [31] and indicates that this is an important limiting factor for intensification of dairy production.

The low level of feed supplementation in the current study (Table 7) resulted in annual feed expenditure being at least $45 \%$ lower per doe than reported for European Mediterranean herds [20,27,43] although government issued feed subsidies [45] were distributed to some holdings during the study period, resulting in expenditure being lower than it otherwise might have been. However, Greek indigenous herds [27] and some Andalusian herds [33,34] have reported similar feed expenditures per doe to CM holdings in the current study. The Greek and Andalusian herds, however, fed more concentrates per doe than in the current study, in addition to not receiving any feed subsidies, suggesting lower feed prices in those regions. This again indicates the constraint on diversification in northern Morocco due to feed access. Feed is often the main cost of livestock production [46], and in the current study, accounted for $72 \%(\mathrm{QCV}=0.18), 69 \%(\mathrm{QCV}=0.38)$ and $35 \%(\mathrm{QCV}=0.82)$ of total expenditure on $\mathrm{CM}, \mathrm{NC}$ and CC holdings respectively (Table 7), despite the subsidies. For CM holdings this value was similar to reports from French dairy herds (79\%) [31], although expenditure per doe was substantially lower in the current study (Figure 5). 
Table 6. Descriptive statistics for parameters relating to goat sales and meat consumption on ten goat holdings in the northern region of Morocco based on monthly data collections between September 2009 and August 2012. Holdings are classified by their dairy production status: commercial cheese (CC, $n=3)$, commercial milk $(\mathrm{CM}, n=4)$ and non-commercial dairy $(\mathrm{NC}, n=3)$.

\begin{tabular}{|c|c|c|c|c|c|c|c|c|c|c|c|c|}
\hline \multirow{2}{*}{ Parameter } & \multirow{2}{*}{ Units } & \multicolumn{4}{|c|}{ All Holdings } & \multicolumn{2}{|c|}{ CC Holdings } & \multicolumn{2}{|c|}{ CM Holdings } & \multicolumn{2}{|c|}{ NC Holdings } & \multirow{2}{*}{ Significance } \\
\hline & & Min. & Median & Max. & CQV & Median & CQV & Median & $\mathrm{CQV}$ & Median & CQV & \\
\hline \multirow[t]{2}{*}{ Home-consumption } & $\mathrm{kg}$ & 29.5 & 133 & 705 & 0.76 & 118 & 0.45 & 127 & 0.90 & 173 & 1.77 & ns \\
\hline & $\mathrm{kg} \cdot$ person $^{-1}$ & 4.00 & 17.7 & 500 & 1.22 & 15.0 & 0.63 & 18.8 & 1.31 & 33.3 & 0.67 & ns \\
\hline \multicolumn{13}{|l|}{ Goat sales } \\
\hline kids & proportion & 0.00 & 0.00 & 0.69 & - & $0.00^{\mathrm{a}}$ & - & $0.01^{\mathrm{b}}$ & 19.2 & $0.00^{c}$ & - & $* * *$ \\
\hline juvenile males & proportion & 0.00 & 0.24 & 1.00 & 2.49 & $0.69^{a}$ & 0.61 & $0.23^{\mathrm{ab}}$ & 2.57 & $0.06^{b}$ & 1.40 & $*$ \\
\hline age & days & 180 & 300 & 360 & 0.25 & 293 & 0.21 & 285 & 0.34 & 315 & 0.14 & ns \\
\hline weight & $\mathrm{kg}$ & 7.00 & 14.0 & 35.0 & 0.54 & 14.0 & 0.20 & 16.0 & 0.44 & 19.0 & 0.00 & ns \\
\hline \multirow[t]{2}{*}{ income } & Euro head $^{-1}$ & 30.0 & 80.0 & 160 & 0.56 & 72.1 & 0.45 & 70.0 & 0.51 & 110 & 0.18 & ns \\
\hline & Euro $\cdot \mathrm{kg}^{-1}$ & 2.32 & 4.77 & 14.6 & 0.44 & 4.26 & 0.32 & 4.64 & 0.18 & 5.79 & 0.14 & ns \\
\hline juvenile females & proportion & 0.00 & 0.02 & 1.00 & 3.92 & $0.06^{\mathrm{a}}$ & 2.23 & $0.00^{b}$ & - & $0.02^{c}$ & 5.05 & $* * *$ \\
\hline age & days & 180 & 300 & 360 & 0.25 & 300 & 0.35 & 360 & 0.08 & 270 & 0.17 & ns \\
\hline weight & $\mathrm{kg}$ & 7.00 & 15.0 & 35.0 & 0.40 & 12.5 & 0.54 & 10.5 & 0.33 & 15.0 & 0.27 & ns \\
\hline \multirow[t]{2}{*}{ income } & Euro head $^{-1}$ & 30.0 & 100 & 145 & 0.42 & 58.0 & 0.51 & 100 & 0.00 & 100 & 0.09 & ns \\
\hline & Euro $\cdot \mathrm{kg}^{-1}$ & 2.32 & 4.77 & 9.67 & 0.64 & 3.83 & 0.50 & 9.52 & 0.36 & 6.67 & 0.16 & ns \\
\hline does & proportion & 0.00 & 0.09 & 0.67 & 0.99 & 0.07 & 0.85 & 0.10 & 2.26 & 0.11 & 0.67 & ns \\
\hline age & days & 365 & 1095 & 4015 & 0.83 & 730 & 1.20 & 1095 & 0.83 & 1600 & 1.13 & ns \\
\hline weight & $\mathrm{kg}$ & 8.00 & 27.0 & 70.0 & 0.44 & 18.0 & 0.28 & 30.0 & 0.37 & 25.0 & 0.48 & ns \\
\hline \multirow[t]{2}{*}{ income } & Euro head $^{-1}$ & 32.0 & 85.3 & 350 & 1.21 & $52.5^{\mathrm{a}}$ & 0.25 & $160^{b}$ & 0.86 & $65.0^{\mathrm{ab}}$ & 0.28 & $*$ \\
\hline & Euro $\cdot \mathrm{kg}^{-1}$ & 0.60 & 4.30 & 24.5 & 0.93 & 2.90 & 0.32 & 5.55 & 0.52 & 3.10 & 2.55 & ns \\
\hline bucks & proportion & 0.00 & 0.00 & 1.00 & - & 0.00 & - & 0.00 & - & 0.00 & - & ns \\
\hline age & days & 365 & 730 & 2920 & 0.48 & $365^{a}$ & 0.16 & $730^{b}$ & 0.50 & $730^{b}$ & 0.23 & $* * *$ \\
\hline weight & $\mathrm{kg}$ & 7.00 & 30.0 & 60.0 & 0.93 & 26.0 & 0.42 & 30.0 & 0.17 & 52.0 & 0.54 & ns \\
\hline \multirow[t]{2}{*}{ income } & Euro head $^{-1}$ & 45.0 & 150 & 430 & 0.32 & $70.0^{\mathrm{a}}$ & 0.24 & $150^{\mathrm{b}}$ & 0.49 & $150^{\mathrm{b}}$ & 0.07 & $* * *$ \\
\hline & Euro $\cdot \mathrm{kg}^{-1}$ & 2.00 & 4.17 & 15.6 & 0.80 & $2.70^{a}$ & 0.30 & $6.20^{b}$ & 0.47 & $4.20^{\mathrm{ab}}$ & 0.59 & $*$ \\
\hline \multirow[t]{3}{*}{ total income } & Euro & 0.00 & 2260 & 11500 & 1.84 & 1730 & 0.42 & 2840 & 1.73 & 5810 & 0.83 & ns \\
\hline & Euro $\cdot$ doe $^{-1}$ & 0.00 & 46.9 & 240 & 0.95 & 42.3 & 0.69 & 52.8 & 1.73 & 62.0 & 0.50 & ns \\
\hline & proportion & 0.00 & 0.67 & 1.00 & 0.86 & $0.61^{a}$ & 0.88 & $0.43^{\mathrm{a}}$ & 0.51 & $1.00^{b}$ & 0.00 & $* * *$ \\
\hline
\end{tabular}

$\mathrm{CQV}=$ coefficient of quartile variation calculated from the interquartile range $\left(\mathrm{Q}_{3}-\mathrm{Q}_{1}\right)$ divided by the median $\left(\mathrm{Q}_{1}\right)$; significant difference between production objectives after accounting

for repeated measured is indicated by different subscripts; level of significance is indicated by asterisks: ${ }^{*} p<0.05,{ }^{* *} p<0.01,{ }^{* * *} p<0.001$; ns, not significant. 
Table 7. Descriptive statistics for parameters relating to the feeding and grazing practices on ten goat holdings in the northern region of Morocco based on monthly data collections between September 2009 and August 2012. Holdings are classified by their dairy production status: commercial cheese (CC, $n=3)$, commercial milk $(\mathrm{CM}, n=4)$ and undiversified (NC, $n=3)$.

\begin{tabular}{|c|c|c|c|c|c|c|c|c|c|c|c|c|}
\hline \multirow{2}{*}{ Parameter } & \multirow{2}{*}{ Units } & \multicolumn{4}{|c|}{ All Holdings } & \multicolumn{2}{|c|}{ CC Holdings } & \multicolumn{2}{|c|}{ CM Holdings } & \multicolumn{2}{|c|}{ NC Holdings } & \multirow{2}{*}{ Significance } \\
\hline & & Min. & Median & Max. & $\mathrm{CQV}$ & Median & CQV & Median & CQV & Median & CQV & \\
\hline \multirow[t]{2}{*}{$\begin{array}{l}\text { Forage } \\
\text { purchases }\end{array}$} & $\mathrm{kg} \cdot \mathrm{doe}^{-1}$ & 0.00 & 0.00 & 153 & - & 9.60 & 11.2 & 0.00 & - & 0.00 & - & ns \\
\hline & Euro $\cdot$ doe $^{-1}$ & 0.00 & 0.00 & 24.7 & - & 1.62 & 8.21 & 0.00 & - & 0.00 & - & ns \\
\hline \multirow[t]{2}{*}{$\begin{array}{l}\text { Coarse } \\
\text { purchases }\end{array}$} & $\mathrm{kg} \cdot \mathrm{doe}^{-1}$ & 0.00 & 0.00 & 146 & - & $0.00^{\mathrm{a}}$ & - & $0.00^{\mathrm{a}}$ & - & $47.4^{\mathrm{b}}$ & 1.65 & $* * *$ \\
\hline & Euro $\cdot$ doe $^{-1}$ & 0.00 & 0.00 & 18.3 & - & 0.00 & - & 0.00 & - & 0.27 & 13.7 & ns \\
\hline \multirow[t]{2}{*}{$\begin{array}{c}\text { Cereal } \\
\text { purchases }\end{array}$} & $\mathrm{kg} \cdot \mathrm{doe}^{-1}$ & 0.00 & 9.58 & 109 & 2.22 & 7.00 & 2.23 & 21.0 & 1.63 & 5.36 & 1.76 & ns \\
\hline & Euro $\cdot$ doe $^{-1}$ & 0.00 & 2.32 & 314 & 3.44 & 1.98 & 2.23 & 7.39 & 1.96 & 1.52 & 2.51 & ns \\
\hline production & Euro $\cdot$ doe $^{-1}$ & 0.00 & 0.00 & 23.4 & - & $0.00^{\mathrm{a}}$ & - & $0.00^{\mathrm{a}}$ & - & $2.87^{b}$ & 3.82 & $* * *$ \\
\hline \multirow{2}{*}{$\begin{array}{l}\text { Concentrate } \\
\text { purchases }\end{array}$} & $k g \cdot d o e^{-1}$ & 000 & 859 & 464 & 963 & $000^{a}$ & - & $933 \mathrm{~b}$ & 113 & $000^{a}$ & - & $* *$ \\
\hline & Euro. doe $e^{-1}$ & $\begin{array}{l}0.00 \\
0.00\end{array}$ & $\begin{array}{l}8.39 \\
3.47\end{array}$ & $\begin{array}{l}464 \\
140\end{array}$ & $\begin{array}{l}9.63 \\
8.05\end{array}$ & $0.00^{\mathrm{a}}$ & - & $38.3^{\mathrm{b}}$ & $\begin{array}{l}1.13 \\
1.29\end{array}$ & $\begin{array}{l}0.00^{\mathrm{a}} \\
0.00^{\mathrm{a}}\end{array}$ & - & $*$ \\
\hline production & Euro $\cdot$ doe $^{-1}$ & 0.00 & 0.00 & 6.24 & - & $0.00^{\mathrm{a}}$ & - & $0.00^{\mathrm{a}}$ & - & $0.82^{b}$ & 0.72 & * \\
\hline \multirow[t]{2}{*}{ Total feed expenditure } & Euro & 0.00 & & & & & & & & & & \\
\hline & Euro $\cdot$ doe $^{-1}$ & 0.00 & 27.5 & 140 & 1.42 & $4.60^{\mathrm{a}}$ & 7.28 & $47.3^{\mathrm{b}}$ & 0.84 & $13.0^{\mathrm{ab}}$ & 0.71 & * \\
\hline $\begin{array}{l}\text { Proportion of total expenditure } \\
\text { Concentrate feeding }\end{array}$ & \multicolumn{12}{|c|}{ Concentrate feeding } \\
\hline does & $\mathrm{kg} \cdot \mathrm{head}^{-1}$ & 0.00 & 42.2 & 183 & 1.85 & $27.0^{\mathrm{a}}$ & 0.78 & $119^{b}$ & 0.62 & $30.0^{\mathrm{a}}$ & 1.43 & $* * *$ \\
\hline bucks & $\mathrm{kg} \cdot \mathrm{head}^{-1}$ & 0.00 & 69.4 & 614 & 2.14 & $6.00^{\mathrm{a}}$ & 5.67 & $159^{b}$ & 0.95 & $22.5^{\mathrm{a}}$ & 5.42 & * \\
\hline juveniles & $\mathrm{kg} \cdot \mathrm{head}^{-1}$ & 0.00 & 17.5 & 71.2 & 2.03 & $7.00^{\mathrm{a}}$ & 2.86 & $38.0^{\mathrm{b}}$ & 0.45 & $0.00^{\mathrm{a}}$ & - & $* * *$ \\
\hline \multicolumn{13}{|l|}{ Grazing } \\
\hline \multirow{2}{*}{ period } & hours day $^{-1}$ & 2.00 & 8.00 & 10.0 & 0.34 & 9.00 & 0.22 & 7.00 & 0.29 & 10.0 & 0.20 & ns \\
\hline & hours. year -1 & 900 & 3030 & 3840 & 0.30 & 3270 & 0.28 & 2550 & 0.19 & 3360 & 0.13 & ns \\
\hline \multirow[t]{2}{*}{ distance } & $\mathrm{km} \cdot$ day $^{-1}$ & 0.20 & 1.00 & 6.00 & 2.25 & 3.00 & 0.93 & 1.00 & 0.31 & 2.50 & 1.00 & ns \\
\hline & $\mathrm{km} \cdot$ year $^{-1}$ & 63.0 & 405 & 2160 & 1.17 & $772^{\mathrm{a}}$ & 0.96 & 360 & 0.06 & 900 & 0.63 & ns \\
\hline
\end{tabular}

$\mathrm{CQV}=$ coefficient of quartile variation calculated from the interquartile range $\left(\mathrm{Q}_{3}-\mathrm{Q}_{1}\right)$ divided by the median $\left(\mathrm{Q}_{1}\right)$; significant difference between production objectives after accounting for repeated measured is indicated by different subscripts; level of significance is indicated by asterisks: ${ }^{*} p<0.05,{ }^{* *} p<0.01, * * * p<0.001$; ns, not significant. 


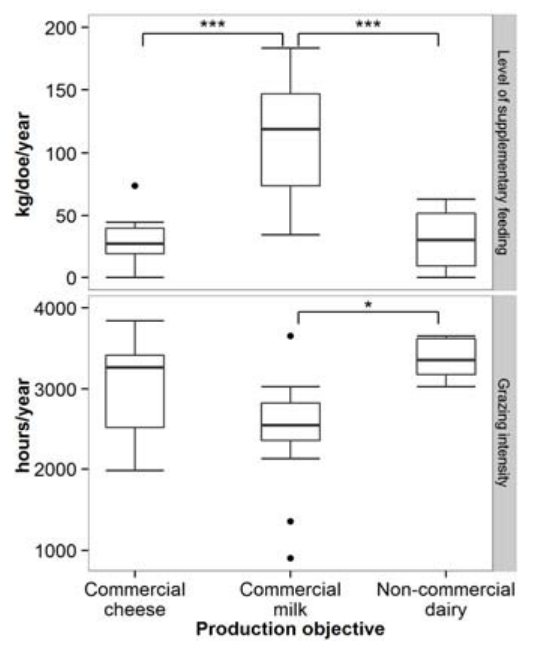

Figure 4. The annual volume of concentrates recevied by does (level of supplementary feeding) and the period of time spent grazing (grazing intensity) on goat holdings in northern Morocco based on monthly data collections between September 2009 and August 2012. Holdings were classified by dairy production status: commercial milk, commercial cheese and non-commercial dairy. Asterisks indicate signficant differences after controlling for repeated measures: ${ }^{*} p<0.05,{ }^{* *} p<0.01,{ }^{* * *} p<0.001$.

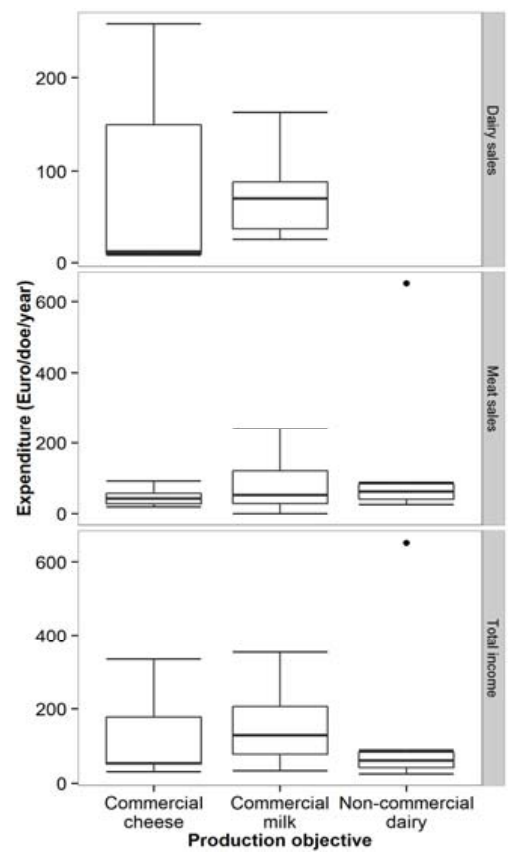

Figure 5. The annual expenditure on veterinary and medicines, feed purchases and production, and total annual expenditure on goat holdings in northern Morocco based on monthly data collections between September 2009 and August 2012. Holdings were classified by dairy production status: commercial milk, commercial cheese and non-commercial dairy.

\subsection{Gross Margin}

Gross margin is the difference between total annual income and expenditure. Total annual income is the sum of the annual income per holding from dairy sales, goat sales and diverse sources (Table 8). An income from diverse sources, typically the sale of manure, was recorded by six holdings (four $\mathrm{CM}$, one CC and one NC holding) and had a low contribution to total income (Table 8). Although 
considerably higher incomes were seen on some CC and CM holdings than NC holdings, there was no significant difference in total income between holding type (Figure 3), which averaged $77.8 € \cdot \mathrm{doe}^{-1}(\mathrm{QCV}=1.41$; Table 8$)$, similar to previous reports for northern Moroccan meat herds [39] but substantially lower than European Mediterranean [25,27,33,35,47] and northern Moroccan [39] commercial dairy herds.

Total annual expenditure is the sum of the recorded annual expenditure on variable costs (feed purchases and production, veterinary and medicine, replacement goat purchases, cheese production and additional costs) per holding (Table 8). Additional costs are the sum of expenditure on supplements, milk replacer, cleaning products, lime, fuel, casual labour, repairs and feed transport costs; it was not possible to segregate these costs, which did not differ significantly between holding type (Table 8). Fixed expenditures, such as the cost of rent and labour, were not included, except for instances where casual labour had been included in feed and diverse production costs and cannot be identified for removal. However, these costs are likely to be low as virtually all labour is unpaid family labour and rented land is uncommon (Table 3). Consequently, net returns are unlikely to differ greatly to gross margin. Despite median annual expenditure being more than double on CM than CC or NC holdings (Figure 5), after controlling for herd size there was no significant difference in total annual expenditure between holding type, which averaged $36.2 € \cdot \mathrm{doe}^{-1}(\mathrm{QCV}=2.09$; Table 8$)$.

Gross margin was negative (expenditure exceeded income) on two holdings during one year of the study. Overall, annual gross margin ranged from -1220 to 7600 Euro (median $=2650 € \mathrm{QCV}=1.10$; Table 8), equivalent to between -14.3 and $239 € \cdot$ doe $^{-1}$ but did not differ holding types (Figure 6). The average gross margin of $36.1 € \cdot \mathrm{doe}^{-1}(\mathrm{QCV}=1.10$; Table 8 ) was more than double that reported previously for meat herds in northern Morocco [22,39] but less than half that reported for cheese and milk producers in Morocco [39] and substantially less than $61.4 € \cdot \mathrm{doe}^{-1}$ reported for indigenous Greek herds [27] achieving similar production results. Somewhat higher gross margins per doe have been reported in Portugal [28] and Andalusia [34], whilst considerably higher gross margins (up to $253 € \cdot$ doe $^{-1}$ ) have been reported for numerous other European Mediterranean studies [27,31,33-35,47]. Gross margin of the herd shows the same differences; this means that the technical underperformance of northern Moroccan goat herds results in a financial underperformance. Therefore the financial cost of any intervention to improve technical performance needs to be outweighed by the improvement in financial income; increasing yields improves food security, but can have negative effects on the farmer [48]. The system may be optimised by improving the goat value chain for increased returns [49].

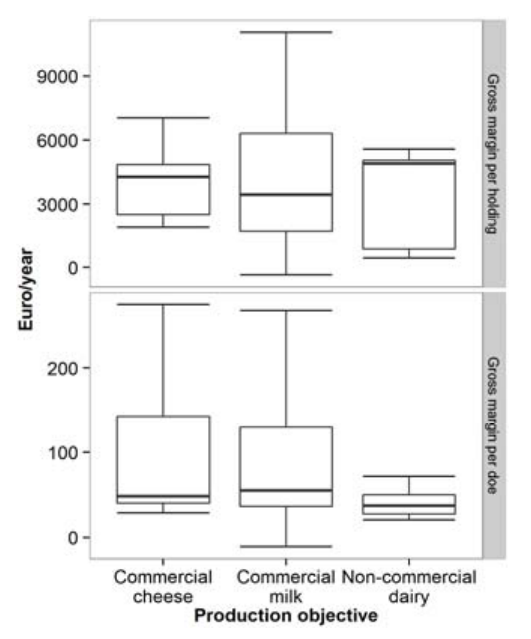

Figure 6. The annual gross margin per holding and annual gross margin per doe on goat holdings in northern Morocco based on monthly data collections between September 2009 and August 2012. Holdings were classified by dairy production status: commercial milk, commercial cheese and non-commercial dairy. 
Table 8. Descriptive statistics for parameters relating to the income, expenditure and gross margin on ten goat holdings in the northern region of Morocco based on monthly data collections between September 2009 and August 2012. Holdings are classified by their dairy production status: commercial cheese (CC, $n=3$ ), commercial milk (CM, $n=4)$ and undiversified (NC, $n=3)$.

\begin{tabular}{|c|c|c|c|c|c|c|c|c|c|c|c|c|}
\hline \multirow{2}{*}{ Parameter } & \multirow{2}{*}{ Units } & \multicolumn{4}{|c|}{ All Holdings } & \multicolumn{2}{|c|}{ CC Holdings } & \multicolumn{2}{|c|}{ CM Holdings } & \multicolumn{2}{|c|}{ UP Holdings } & \multirow{2}{*}{ Significance } \\
\hline & & Min. & Median & Max. & CQV & Median & CQV & Median & $\mathrm{CQV}$ & Median & CQV & \\
\hline \multirow[t]{2}{*}{$\begin{array}{c}\text { Income } \\
\text { dairy }\end{array}$} & Euro. year ${ }^{-1}$ & 6.94 & 46.0 & 258 & 1.70 & 11.9 & 11.8 & 70.6 & 0.73 & - & - & \\
\hline & proportion & 0.09 & 0.44 & 0.99 & 0.78 & 0.39 & 1.46 & 0.55 & 0.35 & - & - & ns \\
\hline \multirow[t]{2}{*}{ meat } & Euro $\cdot$ doe $^{-1}$ & 0.00 & 46.9 & 240 & 0.95 & 42.3 & 0.69 & 52.8 & 1.73 & 62.0 & 0.50 & ns \\
\hline & proportion & 0.00 & 0.67 & 1.00 & 0.86 & $0.61^{a}$ & 0.88 & $0.43^{a}$ & 0.51 & $1.00^{\mathrm{b}}$ & 0.00 & $* * *$ \\
\hline diverse & Euro $\cdot$ doe $^{-1}$ & 0.00 & 0.00 & 840 & $\mathrm{Na}$ & 0.00 & - & 2.56 & 2.36 & 0.00 & - & ns \\
\hline total & Euro $\cdot$ doe $^{-1}$ & 25.4 & 77.8 & 354 & 1.41 & 53.6 & 2.35 & 128 & 1.00 & 62.0 & 0.46 & ns \\
\hline \multicolumn{13}{|l|}{ Expenditure } \\
\hline \multirow[t]{2}{*}{ feed } & Euro $\cdot$ doe $^{-1}$ & 0.00 & 27.5 & 140 & 1.42 & $4.60^{\mathrm{a}}$ & 7.28 & $47.3^{b}$ & 0.84 & $13.0^{\mathrm{ab}}$ & 0.71 & * \\
\hline & proportion & 0.00 & 0.67 & 0.97 & 0.54 & $0.35^{a}$ & 0.82 & $72.2^{b}$ & 0.18 & $0.69 \mathrm{ab}$ & 0.38 & $* *$ \\
\hline herd replacement & Euro $\cdot$ doe $^{-1}$ & 0.00 & 0.00 & 61.8 & - & 0.00 & - & 10.0 & 2.84 & 0.00 & - & ns \\
\hline \multirow[t]{2}{*}{ veterinary and medicines } & Euro $\cdot$ doe $^{-1}$ & 0.00 & 1.80 & 12.2 & 1.24 & 1.30 & 0.85 & 2.25 & 1.93 & 1.60 & 1.38 & ns \\
\hline & proportion & 0.00 & 0.05 & 45.7 & 2.06 & 0.07 & 4.50 & 0.03 & 1.41 & 0.08 & 1.16 & ns \\
\hline \multirow[t]{2}{*}{ cheese production } & Euro $\cdot$ doe $^{-1}$ & 0.00 & 0.25 & 505 & 5.90 & $0.20^{\mathrm{a}}$ & 12.6 & 0.00 & & $0.20^{\mathrm{b}}$ & 1.00 & * \\
\hline & proportion & 0.00 & 0.01 & 0.39 & 12.1 & $0.28^{a}$ & 0.44 & $0.00^{b}$ & - & $0.01^{\mathrm{ab}}$ & 1.65 & $* * *$ \\
\hline & Euro $\cdot$ doe $^{-1}$ & 0.00 & 3.60 & 43.2 & 2.70 & 2.40 & 1.88 & 3.25 & 3.21 & 4.30 & 1.58 & ns \\
\hline \multirow{4}{*}{$\begin{array}{l}\text { total } \\
\text { Gross margin }\end{array}$} & Euro $\cdot$ doe $^{-1}$ & 4.04 & 36.2 & 168 & 2.09 & 14.6 & 4.26 & 97.2 & 0.76 & 19.7 & 0.25 & ns \\
\hline & & & & & & & & & & & & \\
\hline & Euro & -1220 & 2650 & 7600 & 1.10 & 3330 & 0.54 & 1750 & 1.72 & 2886 & 1.22 & ns \\
\hline & Euro $\cdot$ doe $^{-1}$ & -14.3 & 36.1 & 239 & 1.10 & 38.9 & 2.15 & 38.1 & 1.30 & 25.0 & 0.95 & ns \\
\hline
\end{tabular}

CQV, coefficient of quartile variation calculated from the interquartile range $\left(\mathrm{Q}_{3}-\mathrm{Q}_{1}\right)$ divided by the median $\left(\mathrm{Q}_{1}\right)$; significant difference between production objectives after accounting

for repeated measured is indicated by different subscripts; level of significance is indicated by asterisks: ${ }^{*} p<0.05,{ }^{* *} p<0.01,{ }^{* * *} p<0.001$; ns, not significant. 


\subsection{Future Outlook}

The current study, and the results from other Mediterranean grazing goat systems, indicate that the level of supplementary feeding is strongly related to successful dairy goat production; higher levels of supplementary feeding allowing higher productivity. Currently, very few holdings in the region are specialised in dairy production to achieve annual milk yields above 200 litres per doe. These milk yields are only possible when higher levels of supplementary feeding are provided. As there is limited accessible supplementary feed in northern Morocco, it is essential that goat producers are supported to explore alternative feeding and overall production strategies to achieve intensification, rather than focussing solely on an increase in dairy production, particularly as goat meat demand and consumption is also increasing in Morocco.

A lack of accessible feed has traditionally been overcome by herding livestock long distances [45], but is not a feasible option if the aim is to intensify dairy production; this practice can lead to the over-grazing of land [50,51], particularly as the region relies on collective ranges and state forests for grazing which can be difficult to manage sustainably [40] and lack energy and protein during dry periods [52]. It is important to combat desertification and conserve biodiversity in the region [40,53,54] to avoid a high abundance of unpalatable browse, protect long-term food security [55] and safeguard animal health and welfare [41]. Some regions in the Mediterranean have banned rangeland grazing by goats in order to prevent further degradation, but have failed to provide guidance on alternative feed resources [56]. However, under controlled management, grazing is often beneficial to maintenance of open agroecosystems [50,54,57-62]. Both grazing quality and production of supplementary feed are likely to be further compromised in the future as a reduced intensity of precipitation, an earlier onset of drought and an increase in dry days has been predicted in the region $[45,63]$ and has already degraded some rangeland [40]; a shift to sedentary grazing with intensification opposed to the traditional transhumant grazing is further decreasing rangeland productivity and goat performance [50,64]. Therefore supplementary feeding is likely to become an even greater necessity in all goat production systems, regardless of their level of intensity.

One solution is to provide financial support [37] whilst improving import policies and infrastructure for obtaining and distributing feedstuffs. Steps towards this were taken in the 1960s, when the Moroccan government authorities established feed subsidies during periods of drought [45] which are still in operation today [50]; some of these were received by holdings in this study. However, the current study shows that despite this, feed supplementation remains a factor that limits dairy goat production in northern Morocco, possibly because safeguarding of human nutrition, rather than livestock nutrition, is the primary objective during droughts [45] whilst forage production is low [40], highly variable between seasons and years [65] and difficult to control [50]. Furthermore, feed subsidies often result in more sedentary grazing practice, increasing rangeland degradation $[50,66]$. This indicates a need to explore alternative feeding strategies.

Many studies have shown home-produced forage, or limiting purchased feed, to be the most profitable feeding solution [23,65,67-71], with additional environmental benefits. However, forage production is rarely practiced in this region [66]. Therefore a potentially more sustainable approach would be to explore alternative feeding strategies [52], particularly forage options [72], which utilise local resources, are simple and are cost-effective. This will require the guidance of technical advisors [66], as the current socio-economic status of the region limits pasture and forage resource improvement due to insufficient technical support and the vulnerability to drought [40]. The use of alternative feed resources in goat production has been reviewed in detail $[37,52,66,73-76]$ and potential strategies include: by-products from olive production $[77,78]$ which has been promoted under the "plan Maroc vert" agricultural strategy [79]; salt-tolerant shrubs such as saltbush; cactus; ensiling technologies; and feed-blocks of local agro-industrial by-products. Although addition of polyethylene glycol, activated charcoal or calcium hydroxide to the diet can improve rangeland utilisation and goat performance, it can also increase rangeland degradation [76] so should be used with care. 
Adaptive grazing schemes, which combine these alternative feed resources with strategic or conservative rangeland grazing, could balance the insufficient quality and quantity of rangeland resources during periods of high nutritional requirements [50,65], reduce the grazing period [80], reduce grazing pressure on the land [55], reduce the energy expenditure associated with grazing [81,82], reduce the labour requirements associated with herding, and avoid the high costs of imported supplementary feeds which reduce net household income [83]. In addition, a moderate use of alternative feed resources could support dairy production and overall biological performance of the local goat breeds. This could lead to the establishment of a supply-driven, rather than demand-driven, feeding management as part of a whole system approach for the region to further improve the sustainability of intensification [84].

A supply-driven approach balances animal requirements with feed production [85] by matching the system to locally available feed resources, in addition to implementing reproductive management and breeding programmes which complement the characteristics of the region alongside health control programmes [54]; the recent link between the re-emergence of brucellosis, a zoonotic disease, and intensification of livestock production in Morocco [86] in addition to the association of production diseases with intensification [87], highlights the latter element. In this approach, pasture utilisation and alternative feed sources are related to the kidding season [32] and could be more effective than sophisticated genetic improvement programmes [88]. It is also necessary to consider how productivity, management practices and marketing strategies are affected by the environmental, economic and socio-political factors of the region [72]. This concept, applied through a participatory approach, has been successful in many low-input goat systems $[5,44,84,89,90]$ in addition to Moroccan dairy cow systems [91]; farmers' knowledge of the region is supported by that of researchers and extension personnel. This participatory approach, alongside the development of co-operatives [91,92], could improve uptake by farmers and reduce communication gaps between stakeholders [54]. Although factors outside the farmers' control influence farm profit and efficiency, it has been shown that approximately three quarters of the variation in farms reaching their profit potential is a result of farmer management practices [93] and their involvement is therefore paramount.

Whole-farm models may provide further understanding of the complex interaction of biophysical and socioeconomic factors relating to intensification and the value chain $[65,94-97]$. For instance, modelling has shown that in dairy cow systems with restricted feed resources, maintaining low milk yields per animal but increasing herd size to improve overall milk yield is a more favourable strategy than attempting to increase the milk yield per animal [98]. However, a shortage of labour limits herd expansion in this region [22] and larger herd sizes could increase rangeland degradation [83]. In addition to implementing alternative feeding strategies, a mixed meat and dairy semi-intensive production objective based on enhanced local genetics, rather than a specialised dairy system, may increase the technical performance of goat production for greater financial returns and overall financial viability of intensification, whilst helping to meet the increasing demand for and consumption of goat meat in Morocco. This would allow the sale of non-breeding stock at the onset of a drought season to reduce pressure on feed sources later in the season [37]; this may also be a successful rangeland management strategy but only if livestock productivity and mortality rates are not the primary objective [99]. However, this indicates a need to explore very diverse alternative management strategies; the intensive dairy goat model developed in France, and to a lower extent in Spain and Portugal, is unlikely to be successful in Morocco due to the climatic and socio-economic constraints.

The remote location of the goat holdings in this study not only limits their access to resources, but also the distribution of their products; this has been observed in similar systems around the Mediterranean [56]. Therefore, infrastructure improvements will also be key to strengthening the market for goat products in the region [93]; development strategies and policy should focus on education and access to information, distance to markets, herd sizes and availability of alternative feed resources $[56,93,98,100]$. To aid successful commercialisation and market expansion, additional activities are likely to be necessary within the value chain. For instance, producers may be required to 
meet more stringent food safety rules and animal health targets [101], whilst the use of commercial abattoirs could become compulsory for meat production, necessitating the transportation of goats, and dairy production may require pasteurisation procedures and improved cold storage to achieve commercially acceptable shelf-lives. These activities will require both training and financial input [101], and potentially a high level of governance and policy interventions for success [102] through extended and efficient extension services. This aspect is often under-analysed in current value chain research [96], which should attempt to include the effect of climatic shocks and trade barriers, the environmental impact of intensification and the local and regional competition for resources and market for products [96].

\section{Conclusions}

Goats are important contributors to both food and financial security of the resource poor, particularly in marginal environments such as those within the Mediterranean region. Many small-holders in northern Morocco have begun to intensify production through commercialisation of dairy products, under the encouragement of public authorities. However, although the current study showed dairy production to provide an additional rather than alternative income for commercial dairy herds, the need to supply supplementary feed resulted in greater expenditure. Subsequently gross margin per doe was not greater on the commercial dairy holdings. Furthermore, doe and kid mortality rates tended to be higher on holdings with commercial milk or cheese production and reproductive performance was low across all holding types which has negative consequences for both meat and milk yields. With the exception of indigenous Greek herds, extensive and semi-extensive grazing European Mediterranean herds outperform the northern Moroccan herds of the current study in terms of both technical and economic performance; these herds all supplied substantially more supplementary feed, forage in particular, which was sourced at a lower cost. Therefore we conclude that the current cost and availability of supplementary feed in northern Morocco is constraining reproductive success and milk yield which, in turn, limit gross margin and constrains the financial viability of commercial dairy production in the region. Given the predicted effects of climate change on grazing areas in northern Morocco, the most sustainable production method may be a transition to semi-intensive mixed meat and dairy systems which utilise local alternative feeding resources, supported by a participatory approach involving stakeholders from all stages in the value chain; the development of co-operatives could also prove to be highly beneficial. If sufficient, low-cost and local feed can be sourced, it could relieve grazing pressure and increase the goat production yields and overall biological performance, supporting both food and financial security of the region. This will require a very diverse development strategy, specific to Morocco, which enhances the local genetic and feed resources. However, one of the major challenges to ensure the viability of commercial dairy production and meet the growing food demand of Morocco will be the development of extended and efficient extension services to improve infrastructure and value chains within the region.

Acknowledgments: O.F.G. is grateful to the BBSRC SWbio DTP for funding. The authors would also like to thank the farmers involved in the study, in addition to the two anonymous peer reviewers for their thoughtful comments which have been helpful in the work presented in this paper.

Author Contributions: M.C. and B.F.L. designed and managed the data collection; O.F.G. analysed the data and O.F.G. and R.W. interpreted the data and wrote the paper.

Conflicts of Interest: The authors declare no conflict of interest.

\section{References}

1. Aziz, M.A. Present status of the world goat populations and their productivity. Lohmann Inf. 2010, 45, 42-52.

2. Hamadeh, S.K.; Bistanji, G.N.; Darwish, M.R.; Abi Said, M.; Abi Ghanem, D. Economic sustainability of small ruminants production in semi-arid areas of Lebanon. Small Rumin. Res. 2001, 40, 41-49. [CrossRef] 
3. Fitz-Rodríguez, G.; de Santiago-Miramontes, M.A.; Scaramuzzi, R.J.; Malpaux, B.; Delgadillo, J.A. Nutritional supplementation improves ovulation and pregnancy rates in female goats managed under natural grazing conditions and exposed to the male effect. Anim. Reprod. Sci. 2009, 116, 85-94. [CrossRef] [PubMed]

4. Parsons, D.; Nicholson, C.F.; Blake, R.W.; Ketterings, Q.M.; Ramirez-Aviles, L.; Fox, D.G.; Tedeschi, L.O.; Cherney, J.H. Development and evaluation of an integrated simulation model for assessing smallholder crop-livestock production in Yucatan, Mexico. Agric. Syst. 2011, 104, 1-12. [CrossRef]

5. Vayssières, J.; Vigne, M.; Alary, V.; Lecomte, P. Integrated participatory modelling of actual farms to support policy making on sustainable intensification. Agric. Syst. 2011, 104, 146-161. [CrossRef]

6. De Rancourt, M.; Fois, N.; Lavín, M.P.; Tchakérian, E.; Vallerand, F. Mediterranean sheep and goats production: An uncertain future. Small Rumin. Res. 2006, 62, 167-179. [CrossRef]

7. Chentouf, M.; Zantar, S.; Ayadi, M.; Zerrouk, M.; Keli, A. Performances de production et qualité des produits de deux systèmes de production caprine au Nord du Maroc. In Economic, Social and Environmental Sustainability in Sheep and Goat Production Systems; Berneus, A., Boutonnet, J.P., Casasús, I., Chentouf, M., Gabiña, D., Joy, M., López-Francos, A., Morand-Fehr, P., Pacheco, F., Eds.; CIHEAM/FAO/CITA-DGA: Zaragoza, Spain, 2011; pp. 101-106.

8. Chentouf, M. Systèmes de production caprine au nord du Maroc: Contraintes et propositions d 'amélioration. In Technology Creation and Transfer in Small Ruminants: Roles of Research, Development Services and Farmer Associations; Chentouf, M., López-Francos, A., Bengoumi, M., Gabiña, D., Eds.; CIHEAM/INRAM/FAO: Zaragoza, Spain, 2014; pp. 25-32.

9. Chentouf, M.; Bister, J.L.; Boulanouar, B. Reproduction characteristics of North Moroccan indigenous goats. Small Rumin. Res. 2011, 98, 185-188. [CrossRef]

10. Toussaint, G.C.; Morand-Fehr, P.; Castel Genis, J.M.; Choisis, J.P.; Chentouf, M.; Mena, Y.; Pacheco, F.; Ruíz, F.A. Methodologie d'analyse et d'evaluation technico-economique des systemes de production ovine et caprine. In Changes in Sheep and Goat Farming Systems at the Beginning of the 21st Century: Research, Tools, Methods and Initiatives in Favour of a Sustainable Development; Pacheco, F., Morand-Fehr, P., Eds.; CIHAEM/DRAP-Norte/FAO: Zaragoza, Spain, 2009; pp. 327-374.

11. Pittavino, M.; Ferreri, L.; Giacobini, M.; Bertolotti, L.; Rosati, S.; Venturino, E. A CAEV epidemiological model for goat breeding. Appl. Math. Comput. 2014, 227, 156-163. [CrossRef]

12. Capper, J.L. Should we reject animal source foods to save the planet? A review of the sustainability of global livestock production. S. Afr. J. Anim. Sci. 2013, 43, 233-246. [CrossRef]

13. R: A Language and Environment for Statistical Computing; Version 0.99.473; R Core Team: Vienna, Austria, 2015.

14. Bonett, D.G. Confidence interval for a coefficient of quartile variation. Comput. Stat. Data Anal. 2006, 50, 2953-2957. [CrossRef]

15. Bates, D.M.; Maechler, M.; Bolker, B.; Walker, S. lme4: Linear mixed-effects models using Eigen and S4. R Package, Version 1.1-9. Available online: https:/ / cran.r-project.org/package=lme4 (accessed on 23 March 2015).

16. Bolker, B.M.; Brooks, M.E.; Clark, C.J.; Geange, S.W.; Poulsen, J.R.; Stevens, M.H.; White, J.S.S. Generalized linear mixed models: A practical guide for ecology and evolution. Trends Ecol. Evol. 2009, 24, 127-135. [CrossRef] [PubMed]

17. Kuznetsova, A.; Brockhoff, P.B.; Christensen, R.H.B. lmerTest: Tests in Linear Mixed Effects Models. R Package, Version 2.0-29. Available online: https://cran.r-project.org/web/packages/lmerTest/index.html (accessed on 23 March 2015).

18. Castel, J.M.; Mena, Y.; Delgado-Pertiñez, M.; Camúñez, J.; Basulto, J.; Caravaca, F.; Guzmán-Guerrero, J.L.; Alcalde, M.J. Characterization of semi-extensive goat production systems in southern Spain. Small Rumin. Res. 2003, 47, 133-143. [CrossRef]

19. Navarro, M.J.; Fernández, C. Introduction to the situation of the goat sector in the Murcia region (Spain). In Analyse Technico-Économique des Systèmes de Production Ovine et Caprine: Méthodologie et Valorisation Pour le Développement et la Prospective; Mena, Y., Castel, J.M., Morand-Fehr, P., Eds.; CIHEAM/FAO/Universidad de Sevilla: Zaragoza, Spain, 2006; pp. 157-163.

20. Escuder, A.; Fernández, G.; Capote, J. Characterisation of Palmera dairy goat production systems. In Analyse Technico-Économique des Systèmes de Production Ovine et Caprine: Méthodologie et Valorisation pour le Développement et la Prospective; Mena, Y., Castel, J.M., Morand-Fehr, P., Eds.; CIHAEM/FAO/Universidad de Sevilla: Zaragoza, Spain, 2006; pp. 95-100. 
21. Chentouf, M.; Ayadi, M.; Boulanouar, B. Typologie des élevages caprins dans la région de Chefchaouen au nord du Maroc: Fonctionnement actuel et perspectives. In L'évolution des Systèmes de Production Ovine et Caprine: Avenir des Systèmes Extensifs Face aux Changements de la Société; Dubeuf, J.P., Ed.; CIHEAM: Zaragoza, Spain, 2004; pp. 255-261.

22. Chentouf, M.; Ben Bati, M.; Zantar, S.; Boulanouar, B.; Bister, J.L. Evaluation des performances des élevages caprins extensifs dans le nord du Maroc. In Analyse Technico-Économique des Systèmes de Production Ovine et Caprine: Méthodologie et Valorisation pour le Développement et la Prospective; Mena, Y., Castel, J.M., Morand Fehr, P., Eds.; CIHEAM/FAO/Universidad de Sevilla: Zaragoza, Spain, 2006; pp. 87-93.

23. Nahed, J.; Castel, J.M.; Mena, Y.; Caravaca, F. Appraisal of the sustainability of dairy goat systems in Southern Spain according to their degree of intensification. Livest. Sci. 2006, 101, 10-23. [CrossRef]

24. Chentouf, M.; Arrebola Molina, F.; Boulanouar, B.; Mesbahi, H.; Terradillos, A.; Caravaca, F.; Casas, C.; Bister, J.L. Caracterisation des systemes de production caprine semi-extensifs en Andalousie et au nord du Maroc: Analyse comparative. In Changes in Sheep and Goat Farming Systems at the Beginning of the 21st Century: Research, Tools, Methods and Initiatives in Favour of a Sustainable Development; Pacheco, F., Morand-Fehr, P., Eds.; CIHEAM/DRAP-Norte/FAO: Zaragoza, Spain, 2009; pp. 37-41.

25. Sánchez, M.; Gil, M.J.; Fernández, E.; Muñoz, M.E. Application of FAO/CIHEAM indices for dairy systems to dairy goat groups in western Andalusia. In Analyse Technico-Économique des Systèmes de Production Ovine et Caprine: Méthodologie et Valorisation Pour le Développement et la Prospective; Mena, Y., Castel, J.M., Morand-Fehr, P., Eds.; CIHAEM/FAO/Universidad de Sevilla: Zaragoza, Spain, 2006; pp. 187-191.

26. Navarro-Rios, M.J.; Fernández, G.; Perezgrovas, R. Characterization of Majorera goat production systems in the Canary Islands. In Economic, Social and Environmental Sustainability in Sheep and Goat Production Systems; Bernués, A., Boutonnet, J.P., Casasús, I., Chentouf, M., Gabiña, D., Joy, M., López-Francos, A., Morand-Fehr, P., Pacheco, F., Eds.; CIHEAM/FAO/CITA-DGA: Zaragoza, Spain, 2011; pp. 205-210.

27. Kitsopanidis, G.I. Economics of goat farming in Greece. New Medit 2002, 3, 48-53.

28. Pacheco, F. L'élevage caprin dans la montagne, Serra da Peneda: Dynamique et durabilité des systèmes de production, importance des installations et des bâtiments d'élevage. In Analyse Technico-Économique des Systèmes de Production Ovine et Caprine: Méthodologie et Valorisation Pour le Développement et la Prospective; Mena, Y., Castel, J.M., Morand-Fehr, P., Eds.; CIHAEM/FAO/Universidad de Sevilla: Zaragoza, Spain, 2006; pp. 171-178.

29. Usai, M.G.; Casu, S.; Molle, G.; Decandia, M.; Ligios, S.; Carta, A. Using cluster analysis to characterize the goat farming system in Sardinia. Livest. Sci. 2006, 104, 63-76. [CrossRef]

30. Bossis, N.; Caramelle-Holtz, E.; Guinamard, C. Résultats techniques et économiques des exploitations caprines laitières et fromagères fermières en France: Campagne 2003. In Analyse Technico-Économique des Systèmes de Production Ovine et Caprine: Méthodologie et Valorisation Pour le Développement et la Prospective; Mena, Y., Castel, J.M., Morand-Fehr, P., Eds.; CIHEAM/FAO/Universidad de Sevilla: Zaragoza, Spain, 2006; pp. 67-76.

31. Jénot, F. Analyse des résultats technico-économiques d'élevages caprins du département des Deux-Sèvres (France). In Analyse Technico-Économique des Systèmes de Production ovine et Caprine: Méthodologie et Valorisation Pour le Développement et la Prospective; Mena, Y., Castel, J.M., Morand-Fehr, P., Eds.; CIHAEM/FAO/Universidad de Sevilla: Zaragoza, Spain, 2006; pp. 117-123.

32. Castel, J.M.; Mena, Y.; Ruiz, F.A.; Camúñez-Ruiz, J.; Sánchez-Rodríguez, M. Changes occurring in dairy goat production systems in less favoured areas of Spain. Small Rumin. Res. 2011, 96, 83-92. [CrossRef]

33. Ruiz, F.; Castel, J.; Mena, Y.; Camúñez, J.; González-Redondo, P. Application of the technico-economic analysis for characterizing, making diagnoses and improving pastoral dairy goat systems in Andalusia (Spain). Small Rumin. Res. 2008, 77, 208-220. [CrossRef]

34. Ruiz, F.; Mena, Y.; Castel, J.; Guinamard, C.; Bossis, N.; Caramelle-Holtz, E.; Contu, M.; Sitzia, M.; Fois, N. Dairy goat grazing systems in Mediterranean regions: A comparative analysis in Spain, France and Italy. Small Rumin. Res. 2009, 85, 42-49. [CrossRef]

35. Pacheco, F.; Ramos, S.; Rodrigues, C. Évolution De L'Élevage Caprin Traditionnel Dans Le Cadre De La Conversion Au Mode De Production Biologique. In Changes in Sheep and Goat Farming Systems at the Beginning of the 21st Century: Research, Tools, Methods and Initiatives in Favour of a Sustainable Development; Pacheco, F., Morand-Fehr, P., Eds.; Zaragoza, Spain, 2009; pp. 257-260. 
36. Ligios, S.; Carta, A.; Bitti, P.L.; Tuveri, I. Description des systèmes d'élevage caprin en Sardaigne et évaluation des stratégies d'amélioration génétique. In L'évolution des Systèmes de Production Ovine et Caprine: Avenir des Systèmes Extensifs Face aux Changements de la Société; Dubeuf, J.P., Ed.; CIHEAM: Zaragoza, Spain, 2004; pp. 97-104.

37. Ben Salem, H.; Smith, T. Feeding strategies to increase small ruminant production in dry environments. Small Rumin. Res. 2008, 77, 174-194. [CrossRef]

38. Corrias, F.; Brajon, G.; Salari, F.; dal Prà, A.; Ragona, G.; Lombardo, A.; Mari, M.; Altomonte, I.; Colombani, G.; Pedri, P.; et al. Health evaluation in the native Garfagnina goat. Small Rumin. Res. 2012, 104, 191-194. [CrossRef]

39. Chentouf, M.; Zantar, S.; Doukkali, M.R.; Farahat, L.B.; Bouamaa, A.; Aden, H. Performances techniques et économiques des élevages caprins dans le nord du Maroc. In Economic, Social And Environmental Sustainability in Sheep and Goat Production Systems; Bernués, A., Boutonnet, J.P., Casasús, I., Chentouf, M., Gabiña, D., Joy, M., López-Francos, A., Morand-Fehr, P., Pacheco, F., Eds.; CIHEAM/FAO/CITA-DGA: Zaragoza, Spain, 2011; pp. 151-156.

40. Berkat, O.; Tazi, M. Country Pasture/Forage Resource Profiles: Morocco; FAO: Rome, Italy, 2006.

41. Sevi, A.; Casamassima, D.; Pulina, G.; Pazzona, A. Factors of welfare reduction in dairy sheep and goats. Ital. J. Anim. Sci. 2009, 8, 81-101. [CrossRef]

42. Dickhoefer, U.; Nagieb, M.; dos Santos Neutzling, A.; Buerkert, A.; Schlecht, E.; Neutzling, S. Modeling herd development and revenues for Jabal Akhdar goats under current and intensified management practices. Agric. Syst. 2012, 110, 131-141. [CrossRef]

43. Gaspar, P.; Escribano, A.J.; Mesías, F.J.; Escribano, M.; Pulido, A.F. Goat systems of Villuercas-Ibores area in SW Spain: Problems and perspectives of traditional farming systems. Small Rumin. Res. 2011, 97, 1-11. [CrossRef]

44. Ahuya, C.O.; Ojango, J.M.K.; Mosi, R.O.; Peacock, C.P.; Okeyo, A.M. Performance of Toggenburg dairy goats in smallholder production systems of the eastern highlands of Kenya. Small Rumin. Res. 2009, 83, 7-13. [CrossRef]

45. Schilling, J.; Freier, K.P.; Hertig, E.; Scheffran, J. Climate change, vulnerability and adaptation in North Africa with focus on Morocco. Agric. Ecosyst. Environ. 2012, 156, 12-26. [CrossRef]

46. Zaibet, L.; Dharmapala, P.S.; Boughanmi, H.; Mahgoub, O.; Al-Marshudi, A. Social changes, economic performance and development: The case of goat production in Oman. Small Rumin. Res. 2004, 54, 131-140. [CrossRef]

47. Papachristoforou, C.; Markou, M. Overview of the economic and social importance of the livestock sector in Cyprus with particular reference to sheep and goats. Small Rumin. Res. 2006, 62, 193-199. [CrossRef]

48. Alkemade, R.; Reid, R.S.; van den Berg, M.; de Leeuw, J.; Jeuken, M. Assessing the impacts of livestock production on biodiversity in rangeland ecosystems. Proc. Natl. Acad. Sci. USA 2013, 110, 20900-20905. [CrossRef] [PubMed]

49. Pollott, G.E.; Wilson, R.T. Sheep and Goats for Diverse Products and Profits; FAO: Rome, Italy, 2009.

50. Jouven, M.; Lapeyronie, P.; Moulin, C.H.; Bocquier, F. Rangeland utilization in Mediterranean farming systems. Animal 2010, 4, 1746-1757. [CrossRef] [PubMed]

51. Köchy, M.; Mathaj, M.; Jeltsch, F.; Malkinson, D.; Koechy, M. Resilience of stocking capacity to changing climate in arid to Mediterranean landscapes. Reg. Environ. Change 2008, 8, 73-87. [CrossRef]

52. Blache, D.; Maloney, S.K.; Revell, D.K. Use and limitations of alternative feed resources to sustain and improve reproductive performance in sheep and goats. Anim. Feed Sci. Technol. 2008, 147, 140-157. [CrossRef]

53. Hadjigeorgiou, I.; Osoro, K.; Fragoso de Almeida, J.P.; Molle, G. Southern European grazing lands: Production, environmental and landscape management aspects. Livest. Prod. Sci. 2005, 96, 51-59. [CrossRef]

54. Boyazoglu, J. Livestock research and environmental sustainability with special reference to the Mediterranean basin. Small Rumin. Res. 2002, 45, 193-200. [CrossRef]

55. Dickhoefer, U.; Buerkert, A.; Brinkmann, K.; Schlecht, E. The role of pasture management for sustainable livestock production in semi-arid subtropical mountain regions. J. Arid Environ. 2010, 74, 962-972. [CrossRef]

56. Ocak, S.; Davran, M.K.; Güney, O. Small ruminant production in Turkey: Highlighting in goat production. Trop. Anim. Health Prod. 2010, 42, 155-159. [CrossRef] [PubMed] 
57. Fernández-Lugo, S.; Arévalo, J.R.; de Nascimento, L.; Mata, J.; Bermejo, L.A. Long-term vegetation responses to different goat grazing regimes in semi-natural ecosystems: A case study in Tenerife (Canary Islands). Appl. Veg. Sci. 2013, 16, 74-83. [CrossRef]

58. Fernández-Lugo, S.; Bermejo, L.A.; de Nascimento, L.; Méndez, J.; Naranjo-Cigala, A.; Arévalo, J.R. Productivity: Key factor affecting grazing exclusion effects on vegetation and soil. Plant Ecol. 2013, 214, 641-656. [CrossRef]

59. Schaldach, R.; Wimmer, F.; Koch, J.; Volland, J.; Geißler, K.; Köchy, M. Model-based analysis of the environmental impacts of grazing management on Eastern Mediterranean ecosystems in Jordan. J. Environ. Manag. 2013, 127, S84-S95. [CrossRef] [PubMed]

60. Arévalo, J.R.; de Nascimento, L.; Fernández-Lugo, S.; Saro, I.; Camacho, A.; Mata, J.; Bermejo, L. Effects of abandoning long-term goat grazing on species composition and species richness of pastures at La Gomera, Canary Islands. Span. J. Agric. Res. 2011, 9, 113-123. [CrossRef]

61. Fernández-Lugo, S.; de Nascimento, L.; Mellado, M.; Arévalo, J.R. Grazing effects on species richness depends on scale: A 5-year study in Tenerife pastures (Canary Islands). Plant Ecol. 2011, 212, 423-432. [CrossRef]

62. Wachs, E.; Tal, A. Herd no more: Livestock husbandry policies and the environment in Israel. J. Agric. Environ. Ethics 2009, 22, 401-422. [CrossRef]

63. Tebaldi, C.; Hayhoe, K.; Arblaster, J.M.; Meehl, G.A. Going to the extremes: And intercomparion of model-simulated historical and future changes in extreme events. Clim. Change 2006, 79, 185-211. [CrossRef]

64. Chebli, Y.; Mrabet, R.; Chentouf, M. Effect of herd mobility on the species composition and productivity of plant communities in the northern Mediterranean region of Morocco. In New Approaches for Grassland Research in a Context of Climate and Socio-Economic Changes; Acar, Z., López-Francos, A., Porqueddu, C., Eds.; CIHEAM: Zaragoza, Spain, 2012; pp. 303-306.

65. Jouven, M.; Baumont, R.; Ingrand, S.; Bocquier, F. Modelling small ruminant systems in Mediterranean areas. In Changes in Sheep and Goat Farming Systems at the Beginning of the 21st Century: Research, Tools, Methods and Initiatives in Favour of a Sustainable Development; Pacheco, F., Morand-Fehr, P., Eds.; CIHEAM/DRAP-Norte/FAO: Zaragoza, Spain, 2009; pp. 277-292.

66. Ben Salem, H. Nutritional management to improve sheep and goat performances in semiarid regions. Rev. Bras. Zootec. 2010, 39, 337-347. [CrossRef]

67. Gonçalves, A.L.; de Paula Lana, R.; Augusto, R.; Vieira, M.; Henrique, D.S.; Mancio, A.B.; Pereira, J.C. Evaluation of systems of production of dairy goats in the region Southeast of Brazil. Rev. Bras. Zootec. 2008, 37, 366-376. [CrossRef]

68. Fariña, S.R.; Alford, A.; Garcia, S.C.; Fulkerson, W.J. An integrated assessment of business risk for pasture-based dairy farm systems intensification. Agric. Syst. 2013, 115, 10-20. [CrossRef]

69. Benoit, M.; Laignel, G.; Lienard, G.; Dedieu, B.; Chabosseau, J.M. Factors relating to the economic success of extensive sheep farms in Montmorillonnais. Prod. Anim. 1997, 10, 349-362.

70. Morales, A.R.; Galina, M.A.; Jimenez, S.; Haenlein, G.F.W. Improvement of biosustainability of a goat feeding system with key supplementation. Small Rumin. Res. 2000, 35, 97-105. [CrossRef]

71. Ripoll-Bosch, R.; Joy, M.; Bernués, A. Role of self-sufficiency, productivity and diversification on the economic sustainability of farming systems with autochthonous sheep breeds in less favoured areas in Southern Europe. Animal 2014, 8, 1129-1237. [CrossRef] [PubMed]

72. Dubeuf, J.P. Science, technology, innovation and governance for the goat sectors. Small Rumin. Res. 2014, 121, 2-6. [CrossRef]

73. Morand-Fehr, P. Recent developments in goat nutrition and application: A review. Small Rumin. Res. 2005, 60, 25-43. [CrossRef]

74. Papanastasis, V.P.; Yiakoulaki, M.D.; Decandia, M.; Dini-Papanastasi, O. Integrating woody species into livestock feeding in the Mediterranean areas of Europe. Anim. Feed Sci. Technol. 2008, 140, 1-17. [CrossRef]

75. Pearce, K.L.; Norman, H.C.; Hopkins, D.L. The role of saltbush-based pasture systems for the production of high quality sheep and goat meat. Small Rumin. Res. 2010, 91, 29-38. [CrossRef]

76. Rogosic, J.; Estell, R.E.; Ivankovic, S.; Kezic, J.; Razov, J. Potential mechanisms to increase shrub intake and performance of small ruminants in mediterranean shrubby ecosystems. Small Rumin. Res. 2008, 74, 1-15. [CrossRef] 
77. Molina Alcaide, E.; Nefzaoui, A. Recycling of olive oil by-products: Possibilities of utilization in animal nutrition. Int. Biodeterior. Biodegrad. 1996, 38, 227-235. [CrossRef]

78. Molina Alcaide, E.; Yáñez Ruiz, D.; Moumen, A.; Martín García, I. Chemical composition and nitrogen availability for goats and sheep of some olive by-products. Small Rumin. Res. 2003, 49, 329-336. [CrossRef]

79. Agency of Partnership for Progress (MCA-Morocco) Improving Production and Quality in the Olive Oil Sector; Rabat, 2008. Available online: http://www.mcc.gov/documents/investmentopps/bom-moroccoenglish-oliveoil.pdf. (accessed 9 November 2015).

80. Bordi, A.; de Rosa, G.; Napolitano, F.; Vesce, G.; Rubino, R. Influence of feeding supplementation on goats grazing behaviour. In Grazing Behaviour of Goats and Sheep; Gordon, I.J., Rubino, R., Eds.; CIHEAM: Zaragoza, Spain, 1996; pp. 57-68.

81. Lachica, M.; Aguilera, J.F. Energy needs of the free-ranging goat. Small Rumin. Res. 2005, 60, 111-125. [CrossRef]

82. Lachica, M.; Aguilera, J.F. Energy expenditure of walk in grassland for small ruminants. Small Rumin. Res. 2005, 59, 105-121. [CrossRef]

83. Briske, D.D.; Zhao, M.; Han, G.; Xiu, C.; Kemp, D.R.; Willms, W.; Havstad, K.; Kang, L.; Wang, Z.; Wu, J.; et al . Strategies to alleviate poverty and grassland degradation in Inner Mongolia: Intensification $v s$. production efficiency of livestock systems. J. Environ. Manag. 2015, 152, 177-182. [CrossRef] [PubMed]

84. Alexandre, G.; González-García, E.; Lallo, C.H.O.; Ortega-Jimenez, E.; Pariacote, F.; Archimède, H.; Mandonnet, N.; Mahieu, M. Goat management and systems of production: Global framework and study cases in the Caribbean. Small Rumin. Res. 2010, 89, 193-206. [CrossRef]

85. Jouven, M.; Baumont, R. Simulating grassland utilization in beef suckler systems to investigate the trade-offs between production and floristic diversity. Agric. Syst. 2008, 96, 260-272. [CrossRef]

86. Ducrotoy, M.J.; Ammary, K.; Ait Lbacha, H.; Zouagui, Z.; Mick, V.; Prevost, L.; Bryssinckx, W.; Welburn, S.C.; Benkirane, A. Narrative overview of animal and human brucellosis in Morocco: Intensification of livestock production as a driver for emergence? Infect. Dis. Poverty 2015, 4, 57. [CrossRef] [PubMed]

87. Faye, B.; Lancelot, R. Ecopathological approach in tropical countries: A challenge in intensified production systems. Ann. N. Y. Acad. Sci. 2006, 1081, 137-146. [CrossRef] [PubMed]

88. Dubeuf, J.P.; Boyazoglu, J. An international panorama of goat selection and breeds. Livest. Sci. 2009, 120, 225-231. [CrossRef]

89. Alcedo, M.J.; Ito, K.; Maeda, K. Stockmanship competence and its relation to productivity and economic profitability: The context of backyard goat production in the Philippines. Asian Australas. J. Anim. Sci. 2015, 28, 428-434. [CrossRef] [PubMed]

90. Alexandre, G.; Mandonnet, N. Goat meat production in harsh environments. Small Rumin. Res. 2005, 60, 53-66. [CrossRef]

91. Srairi, M.T.; El Jaouhari, M.; Saydi, A.; Kuper, M.; le Gal, P.Y. Supporting small-scale dairy farmers in increasing milk production: Evidence from Morocco. Trop. Anim. Health Prod. 2011, 43, 41-49. [CrossRef] [PubMed]

92. Morand-Fehr, P.; Boutonnet, J.P.; Devendra, C.; Dubeuf, J.P.; Haenlein, G.F.W.; Holst, P.; Mowlem, L.; Capote, J. Strategy for goat farming in the 21st century. Small Rumin. Res. 2004, 51, 175-183. [CrossRef]

93. Bahta, S.; Malope, P. Measurement of competitiveness in smallholder livestock systems and emerging policy advocacy: An application to Botswana. Food Policy 2014, 49, 408-417. [CrossRef]

94. Connor, D.J.; van Rees, H.; Carberry, P.S. Impact of systems modelling on agronomic research and adoption of new practices in smallholder agriculture. J. Integr. Agric. 2015, 14, 1478-1489. [CrossRef]

95. Bosman, H.G.; Moll, H.A.J.; Udo, H.M.J. Measuring and interpreting the benefits of goat keeping in tropical farm systems. Agric. Syst. 1997, 53, 349-372. [CrossRef]

96. Rich, K.M.; Ross, R.B.; Baker, A.D.; Negassa, A. Quantifying value chain analysis in the context of livestock systems in developing countries. Food Policy 2011, 36, 214-222. [CrossRef]

97. Tedeschi, L.O.; Nicholson, C.F.; Rich, E. Using System Dynamics modelling approach to develop management tools for animal production with emphasis on small ruminants. Small Rumin. Res. 2011, 98, 102-110. [CrossRef]

98. Bartl, K.; Mayer, A.C.; Gómez, C.A.; Muñoz, E.; Hess, H.D.; Holmann, F. Economic evaluation of current and alternative dual-purpose cattle systems for smallholder farms in the central Peruvian highlands. Agric. Syst. 2009, 101, 152-161. [CrossRef] 
99. Hahn, B.D.; Richardson, F.D.; Starfield, A.M. Frame-based modelling as a method of simulating rangeland production systems in the long term. Agric. Syst. 1999, 62, 29-49. [CrossRef]

100. Castel, J.M.; Ruiz, F.A.; Mena, Y.; Sánchez-Rodríguez, M. Present situation and future perspectives for goat production systems in Spain. Small Rumin. Res. 2010, 89, 207-210. [CrossRef]

101. Nahed, T.J.; Mena, G.Y.; Castel, G.J.; Caravaca, R.F. Resource Management Strategies in Goat Agroecosystems of Mountain Areas in Andalucia (Spain): Case Study in Cadiz Mountain Range; Castelan Ortega, O.A., Bernues Jal, A., Ruiz Santos, R., Mould, F.L., Eds.; UAEM: Mexico, Mexico, 2008.

102. Bowman, M.S.; Zilberman, D. Economic factors affecting diversified farming systems. Ecol. Soc. 2013, 18, 33-46. [CrossRef]

(C) 2016 by the authors; licensee MDPI, Basel, Switzerland. This article is an open access article distributed under the terms and conditions of the Creative Commons Attribution (CC-BY) license (http://creativecommons.org/licenses/by/4.0/). 